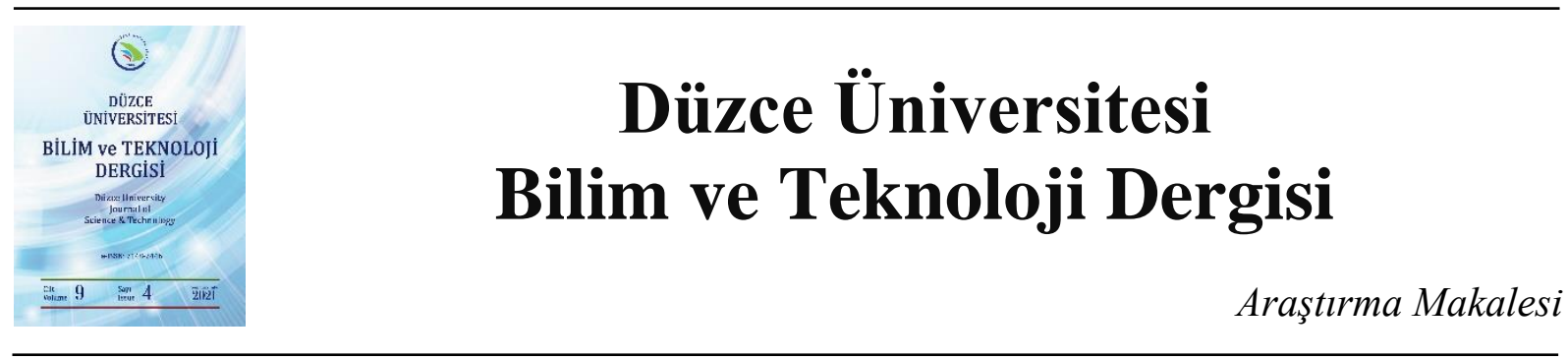

\section{Yürünebilirliğin Nitel ve Nicel Veriler Üzerinden Ölçülmesi; Düzce Örneği}

\author{
Zeynep MIHÇI $^{\mathrm{a}}{ }^{\text {,* }}$ (D) Ayşegül TANRIVERDİ KAYA ${ }^{\mathrm{b}}$ \\ ${ }^{a}$ Mimarlık Bölümü, Sanat Tasarım ve Mimarlık Fakültesi, Düzce Üniversitesi, Düzce, TÜRKIYYE \\ ${ }^{b}$ Mimarlık Anabilim Dall, Fen Bilimleri Enstitüsü, Düzce Üniversitesi, Düzce, TÜRKIYE \\ * Sorumlu yazarın e-posta adresi: zeynep75911@duzce.edu.tr
}

DOI: $10.29130 /$ dubited.844165

\begin{abstract}
ÖZ
Yürümek bireylerin günlük hayatlarında sıklıkla yaptıkları kolay ve kullanışlı bir ulaşım çeşididir. Aynı zamanda sağlıklı bir aktivite olan yürüme, bireyler arasındaki etkileşimi arttırmakla kalmayıp, kent kullanıcılarının ekonomik olarak kalkınmasını, sosyalleşmesini sağlarken, kent ile kentli arasında bağ oluşmasına da yardımcı olmaktadır. Dolayısıyla yürünebilirlik mekânda yaşam kalitesi ve yaşanabilirlik ile bağdaştırılan fiziki bir ölçüt olarak kabul edilmektedir. Yürünebilirlik kavramı, fiziki mekânlarda ölçülebilir bir kavramdır. Toplumsal mekânı yürünebilirlik açısından değerlendirmek için niteliksel ve niceliksel olmak üzere kentsel tasarım ölçütleri bulunmaktadır. Bu araştırma yürünebilirlik olgusunu nitel ve nicel veriler üzerinden ölçmeyi hedeflemektedir. Düzce ili Spor Sokak ve Gaziantep Caddesi çalışma alanı olarak seçilmiştir. Çalışmada nitel verileri elde etmek ve mekânsal algının ölçülmesi için anket yöntemi, nicel verileri elde etmek için ise, kaynak tarama, gözlem, fotoğraflama, GIS gibi yöntemler kullanılmıştır. Ankette katılımcıların sosyo-demografik yapı analizi yapıldıktan sonra mekâna yönelik algılarını ölçmek adına canlılık, çeşitlilik, kimlik, anlaşılabilirlik, güvenlik, konfor ve bağlantılılık ile ilgili sorular sorulmuştur. Mekansal analizler için ArcGIS (10.7) programı kullanılmıştır. Toplanan veriler sokak ölçeğinde yürünebilirlik ile ilişkilendirilmiştir. Kentsel mekân olan sokakların her yaş, cinsiyet ve sosyo-kültürel gruptan insanlara hitap edecek şekilde tasarlanmasının yürünebilirliği artıran önemli bir etmen olduğu, çeşitlilik ve ulaşılabilir olma özellikleri ile de desteklenmesi gerektiği sonucuna varılmıştır. Tasarım kararları alınmadan önce bu gibi sosyal analizlerin yapılmasının önemli olduğu görülmektedir. Bu çalışmanın bölgede yapılması planlanan kentsel tasarım projelerine bir altlık olabileceği düşünülmektedir.
\end{abstract}

Anahtar Kelimeler: Algl, Mekansal algl, Nitel veriler, Nicel veriler, Yürünebilirlik

\section{Measuring Walkability by Qualitative and Quantitative Data; Düzce Case}

\begin{abstract}
Walking is an easy and convenient form of transportation that individuals often do in their daily lives. At the same time, walking is a healthy activity, that does not only increase the interaction between individuals but also helps urban users to develop and socialize economically and to create a connection between the urban realm. The concept of walkability is a measurable concept in physical spaces and can be evaluated by urban design criteria which are both qualitative and quantitative, to measure social space in terms of walkability. The perceptibility of the urban space is an important phenomenon that establishes the communication between the citizen and the city gives clues about the architectural space and enables the use of these experiences when designing new spaces. While perception is the experience created by the stimuli coming from the environment and received directly, perceptibility is the effect of the properties of the surrounding objects and various stimuli on the perception. This
\end{abstract}


research aims to measure the walkability phenomenon over qualitative and quantitative data. Düzce province Spor Sokak and Gaziantep Street were selected as the study area. In the study, the survey method was used to obtain qualitative data, and methods such as literature research, observation, photographing, and GIS were used to obtain quantitative data. ArcGIS (10.7) software was used for spatial analysis. In the survey, after analyzing the sociodemographic structure of the participants, questions were asked about vitality, diversity, identity, intelligibility, security, and comfort in order to measure their perception of the place. It has been concluded that the design of urban streets to appeal for people of all ages, genders and socio-cultural groups is an important factor that increases walkability and should be supported with diversity and accessibility features. It seems important to conduct such social analysis before making design decisions. It is thought that this study can be a basis for the urban design projects planned to be made in the region.

Keywords: Perception Spatial perception, Qualitative data, Quantitative data, Walkability

\section{GİRIS}

Yürüme eylemi insanların yüzyıllardan beri süregelen alışkanlıklarından biridir. Kimi zaman bir yerden bir yere ulaşma amacı taşıyan kimi zaman ise insanların topluluklara katılarak kendi kimliğini ortaya koymasına yardımcı olan bir aktivitedir. Bu aktivite ile insanlar çevrelerini algılamaya başlayarak geçip gittiği veya bulunduğu mekanları anlamaya böylece bu mekanları yaşamaya başlar. İnsan sağlığı bakımından da yürümenin önemi oldukça büyüktür. Sağlık sorunları (obezite, kalp ve akciğer rahatsızlıkları vb.) artmaya başlayan toplumlarda yürümenin ve yürünebilirliğin kullanımının azaldığı görülmektedir.

Kentsel tasarımın en önemli bileşenlerinden olan yaya hareketleri, sosyal etkileşim ve bunun sonucu olarak ortaya çıkan mekânsal ve ekonomik canlılığı arttırması sebebi ile de günümüzde tasarımcı ve kent planlamacılarının odak noktası haline gelmiştir [1]. Bununla birlikte çok sayıda yayanın kullanacağı mekanlar yeni yatırımcıları bu cazip mekanlara yönlendirmektedir. Bu sayede bu alanlarda iş ve istihdam olanaklarının artması ile mekanların cazibesinin artmasını sağlamaktadır. Yürünebilir çevrelerin tasarımı çok farklı unsurun bir arada uyum içerisinde bulunmasını gerektirmektedir. $\mathrm{Bu}$ çevrelerin tasarımı günümüzde kent tasarımcıları ve ulaşım planlamacılarının etkisi altındadır. Kent tasarımcıları durumu daha küçük ölçekten ve detayları ile değerlendirirken ulaşım planlamacılar daha büyük ölçekten genel hatları ile ele almaktadır.

Yürünebilirliğin ölçülebilir bir kavram olması mekânların kapasitelerinin bazı niteliksel ve niceliksel veriler yardımıyla incelenebilir olması ile ilgilidir. Yürüme ve yürünebilirlik olgusunu inceleyen bu çalışmanın amacı; elde edilen nitel ve nicel veriler ile çalışma alanı olarak seçilen sokak ve caddelerin yürünebilirliğinin ölçülmesidir. Çalışma, mekansal uyarım sonucu ortaya çıkan, niceliksel olarak ölçülemeyen algısal yargıların; mekanların fiziksel bileşenlerinin niteliksel olarak ölçülmesi sonucunda aralarındaki ilişkinin somut verilerle açıklanması bakımında önemlidir.

\section{KAVRAMSAL ALTYAPI}

\section{A. YÜRÜNEBILLIRLİK VE TASARIM ÖLÇÜTLERİ}

Yürünebilirlik; bir yerden bir yere ulaşmayı sağlayan hareket eylemini tanımlayan bir kavramdır. Yürüme eyleminin en basit ve masrafsız olan halidir [2]. Fiziksel çevre-insan arasındaki ilişkinin kurulmasının ise, en elverişli biçimi olarak karşımıza çıkmaktadır. Hutabarat (2009) [3]'da her yaş grubundan insanın temel fiziksel aktivitesi olan yürüme eylemini; basit ve ekonomik bir ulaşım biçimi olarak tanımlamıştır. Yürüme sadece bir ulaşım şekli değil aynı zamanda kentsel tasarımı belirleyen unsurların (sokak dokusu, kaldırım genişliği/niteliği, yolun durumu, yapılı çevre vb.) sayesinde kamusal yaşama dahil olabilme ve sosyalleşmenin aracidır [4]. Greenberg (2005) [5], yürüme eyleminin kendisinin bir amaç olduğunu belirtmektedir. Southworth (2005) [6] ve Yazıcıoğlu Halu (2010) [7], yürünebilirliği "yayaları yürümeye cesaretlendiren bir yapılı çevrenin ötesinde, konforu ve güvenliği 
sağlayan, makul zaman ve mesafede farklı güzergahlarda çeşitli insanlarla iletişime imkan veren ve sokak örüntüsünde gezinirken görsel çekicilik sunan mekan" olarak tanımlamaktadır. Kısaca yürünebilirlik, fiziksel çevre ve bireysel faktörlerin etkisi altında özne-nesne etkileşiminde gerçekleşen bir olgu olarak tanımlanabilir [8], [9].

Bradshaw (1993) [10]'e göre yürünebilirliği etkileyen dört temel etken vardır. Bunlar; konfor koşulları, kullanımlar, doğal çevre ve yerel kültürdür. Litman (2003) [2]'e göre ise yürünebilirliğin temelinde yürüyüş olanakları ve güvenliğinin olması, konfor ve rahat yürüme, yürüme koşullarının kalitesi yatmaktadır. Yürünebilirliği belirsiz olarak gören Krambeck (2006) [4] ise, ölçümünün tartışmalar ve uyuşmazlıklara sebep olabileceğini savunmaktadır.

Yürünebilirliğin ölçülmesi onu etkileyen faktörlerin bilinmesi ile daha sağlıklı bir şekilde gerçekleştirilebilir (Şekil 1). Literatürde yürünebilirliği etkileyen faktörler birçok kez tartış1lmıştır. Bu tartışmalarda; mekan algısı ve bireysel tepkiler daha çok öne çıkmıştır [11], [12]. İşlevlerin/kullanımların çeşitliliği, bağlantılar, konfor ve güvenlik fiziksel çevre faktörleri içerisinde yer almaktadır [9]. (Ewing vd. (2006) [11]'ya göre mekanın algısal niteliği ile ilişkilendirilen kavramlar; okunabilirlik ve zihinde canlandırma, kapalılık, insan ölçeği, saydamlık ve karmaşıklıktır. Kültür ve fiziksel algısal karakteristik yürüme eylemini en çok etkileyen unsurlardır. Çünkü bu iki faktör en genel tanımda diğer faktörleri içermektedir. Jacobs, (2011) [13], sokak kullanımını ölçek, yoğunluk, mekan kalitesi, erişilebilirlik ve güvenlik kavramları ile ilişkilendirmiştir. Kriken ve diğ. (2010) [14], sürdürülebilirlik, erişebilirlik, çeşitlilik, açık mekan, uyumluluk, adapte olabilme, teşvik, yoğunluk ve kimlik kavramlarını planlama kriteri olarak belirlemişlerdir. Saelens ve di ̌̆. (2003) [15]'ne göre yürünebilirlik; yoğunluk, çeşitlilik, erişilebilirlik, bağlantılılık, yürümek ve bisiklet kullanmak için yolların varlığı, estetik, trafik ve suç oranı gibi faktörlere bağlıdır. Bu yaklaşımlardan yola çıkarak bu çalışma için yürünebilirliği önemli ölçüde etkileyen fiziksel çevre kriterinden bağlam, erişilebilirlik, çeşitlilik, ölçek, yoğunluk, güvenlik ve konfor kavramları seçilmiştir.

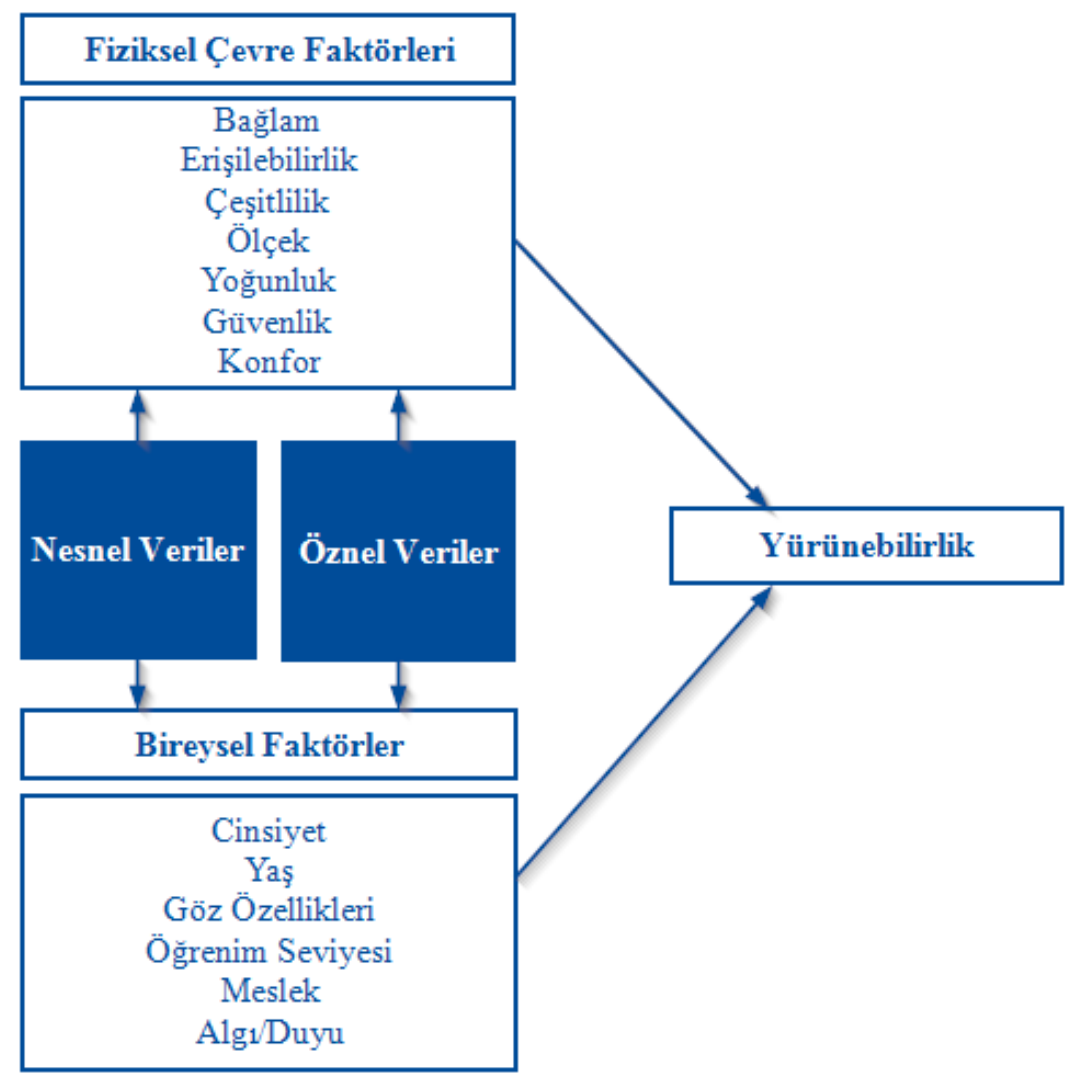

Şekil 1. Yürünebilirlik [8]. 


\section{A. 1. Bağlam}

Bağlam, yapı alanı topografyası ile koşulları bakımından öne çıkarken; doğal, yapay ve fiziksel şartlar ile oluşan sosyal, kültürel, ekonomik ve tarihi çevre olarak da tanımlanabilir [16], [17]. Kimi araştırmacılara göre ise bağlam çevreye ait fiziksel koşullar ve verilerden oluşmaktadır.

Yürünebilirlik kapsamında bağlam çoğunlukla yapılı çevrenin karakteriyle alakalıdır. Yürünebilir yapılı çevrenin bağlamı mekanın karakteri ile doğrudan ilişkilidir. Yürünebilirlik kapsamında sokağın ve kentsel bölgenin veya kentin kendisi bağlamı oluşturmaktadır. Bu durum ölçeğin değişimine göre farklıl1k göstermektedir. Küçük yerleşimlerde sokağın ve yerleşimin karakteri bağlamı etkilerken, büyük ölçekli metropollerde sadece sokağın kendisi veya kentsel bölgenin kendisi bağlamı etkilemektedir [18].

\section{A. 2. Erişilebilirlik}

Erişilebilirlik, kavramsal olarak kullanıldığı yere göre farklı şekillerde ele alınmış ve tanımlanmıştır. Literatürde en yaygın olarak; "etkileşimi arttıracak olanakların potansiyeli" (Hansen, 1959) [19], "bireylerin özgürce farklı aktivitelere katılabilmesi" Burns, (1979) [20], "insanların ve ticari öğelerin kolay bir şekilde istediği tesis, ürün ve aktivitelere ulaşabilmesi” Bhat ve diğ., (2001) [21] şeklinde tanımlanmıştır. Yapılan literatür araştırmalarında yolcuların istasyon vb. ulaşım tesislerine kolay ulaşması bölgenin erişilebilirlik düzeyini belirlediği görülmektedir [22].

Yayanın kentin sokaklarında ve caddelerinde ne kadar hareket edebildiğini gösteren erişilebilirlik yol şemasının biçimlenişiyle ve yapı adalarının büyüklüğüyle yakından ilişkilidir [6], [14]. Otomobil odaklı geniş caddeler ve geniş yap1 adaları yürünebilir veya yaya dostu değildir. Bunun yerine dar caddelerin ve küçük yapı adalarının bulunduğu örüntüler daha geçirgen ve erişilebilirdir [14]. Yaya erişilebilirliği kentsel mekanın nasıl biçimlendiğiyle alakalıdır. Yeterli ve güvenli yaya yollarının kaldırımlarının olması ve kesintiye uğramaması önemlidir. Yayalar her zaman eğimli yola oranla düz yolu tercih ederler. Yolun eğiminin artması, yolun yürünebilirliğini olumsuz etkiler [23]. Kaldırım taşının yapısı da bazı kullanıcılar için her zaman uygun olmayabilir. Yüzeyi engebeli girintili çıkıntılardan oluşan kaldırım taşları tekerlekli yayalar veya topuklu ayakkabı giyen kadınlar için erişilebilir olmadığından kullanımı da tercih edilmez. Yeterli ve kesintisiz kaldırımların olması kentsel mekanda erişilebilirliği arttırırken kentlerin daha erişilebilir olması yol çizelgesinin sürekli ve bağlantılı olması ile sağlanabilir. Süreklilik, yolların ne kadar devamlı olduğuyla ilgilidir. Yolun bağlantılılı̆̆ı ise bir yolun diğer yollarla ne sıklıkla ve doğrulukta kesiştiğiyle ilgilidir. Süreklilik ve bağlantılılığın belli bir hiyerarşisi bulunmaktadır. $\mathrm{Bu}$ hiyerarşi ölçüsünde optimum seviyelerde kurulan yol şeması yayalar için daha erişilebilir bir kent oluşturur.

\section{A. 3. Çeşitlilik}

Çeşitlilik genel anlamda bakıldığında pek çok sosyal ve ekonomik faydaları olan bir kavramdır. Kamusal aktivitelerin çeşitlendirilmesi ile mekanların çekiciliği artar bu sayede ekonomi canlanır. Farklı aktivite merkezlerinin oluşmasına katkı sağlamış olur. Kamusal alanlarda zaman ve mekanlarını paylaşan insanlar arasında sosyal yakınlaşma ve topluluk duygusu oluşmaya başlar. İnceoğlu (2007) [24]'nin tanımına göre ise çeşitlilik; sosyalleşebilme, her yaştan insanın bir arada var olabilmesi, çeşitli aktivitelerin ve alışveriş imkanlarının sunulmasıdır. Ewing ve diğ., (2011) [25], [1] çeşitliliği "Belli bir alanda farklı kullanım(fonksiyon) çeşitlerini barındırarak, kısa mesafelerde birçok yeri erişilebilir kılan yerin karma kullanımı" anlamında kullanmaktadır. Karma kullanım; farklı fonksiyonların (konaklama, iş, konut, eğlence ve ticaret vb.) bir araya getirilmesidir. Böylece günün 24 saati işleyen mekanların oluşması ve etkin kullanılması sağlanmış olur [14].

Kentsel çeşitlilik ise canlı sokak yaşantısının en önemli etkenlerinden birisidir. Mekan kullanımı ve kullanıcı arasındaki ilişkiyi etkileyen yapılı çevre düzenlemeleri farklı fonksiyonları bir arada 
bulundurduğu takdirde kentsel çeşitliliği arttırır [26], [1]. Çeşitliliğin çok olduğu canlı kentler birbirine geçmiş, net bir ayrım yapılamayan, bütün mekanlarının iç içe olduğu kentlerdir.

\section{A. 4. Ölçek}

Ölçek kavramı ile ilgili literatürde pek çok tanımlama bulunmaktadır. Günümüzde yapılan araştırmalarda kavram daha çok niceliksel yönleri karşımıza çıkmaktadır. Ölçek, herhangi bir şeyin boyutunun referans alınan standartla kıyaslanması ile bulunabilir [27]; görece hangi oranda küçük veya hangi oranda büyük olduğunu anlamaya yardımcı olur. Kıyaslama yapılırken çoğunlukla insan imgesi kullanılmaktadır [28]. Ching'e göre bir şeyin verdiği büyüklük hissi insan ölçeğine karşılık gelmektedir [29]. Kentsel mekandaki insan ölçeğini ise kent mobilyası, cadde genişlikleri ve hizmetler ile ihtiyaçlara yürüyerek ulaşabilme yansıtmaktadır [30].

Yapılı çevrede ölçeği kıyaslayabileceğimiz en önemli unsurlar; bina yükseklikleri ve büyüklükleri, yapı adası büyüklükleri ve sokak genişlikleridir. Yürünebilirlikle ilişkisini incelemek için ise genellikle kentsel mekandaki sokak ve kaldırımların genişlikleri, yapıların yükseklikleri, yapı adalarının büyüklüğü, sokak donatılarının büyüklüğü, yolun genişliği vb. etkenlere bakılmaktadır. Yürünebilir çevre kentsel mekanın bu niteliklerinin insan ölçeğinde olduğunda sağlanmaktadır.

\section{A. 5. Yoğunluk}

Yoğunluk genel anlamda birim alandaki insan, iş ya da konutun ölçülmesiyle tanımlanmaktadır. [25]. Tasarımın yoğun ve kompakt olması daha çok ve daha kullanışlı kentsel alanların olması ile ilgilidir. Mekan kullanımının yoğunluğu ne kadar fazla ise insan yoğunluğu da o mekanlarda aynı oranda fazla olacaktır [31], [1]. Yaşayan kentlerin oluşabilmesi için kentlerin belli bir yoğunluğa erişmiş olması gerekir [13]. Yoğunluk tasarlanırken bazı tasarım kriterlerine dikkat edilmelidir. Mesela insanlar yürüme mesafesinde tüm ihtiyaçlarına ulaşabilmelidir. Ayrıca bu bölgelerin tasarımında sokaklar güneş ışığından faydalanabilecek ölçüde geniş olmalıdır ki bu da insanların güneş 1şı̆̆ından faydalanabilmesi açısından önemlidir [14]. Yapıların yüksekliği arttıkça kullanıcı sayısı da artacağından sokaklardaki yaya yoğunluğu artacaktır [32], [1]. Bu yoğunluğu karşılayabilecek kapasitede sokak ve ihtiyaçların karşılanması oradaki yürünebilirlik açısından önemlidir. Yoğunluğun arttığı oranda yaya çevrelerinin de geliştirilmesi gerekmektedir. Tek başına yoğunluk canlılık anlamına gelmez [23]. Yoğunluğun başarılı olabilmesi optimum seviyede tutulmasında gizlidir.

\section{A. 6. Güvenlik}

Yürünebilir sokakların oluşmasında en çok etkisi olan etmenlerden biri de güvenlik unsurudur. İnsanlar kendilerini güvende hissettikleri alanlarda yürümeyi tercih ederler. Literatür taramasında suç oranlarındaki temel etmenin yapılı çevrenin fiziksel özellikleri olduğu görülmektedir. Alfonzo (2005) [33]'e göre güvenliğin sağlanması kentsel tasarım, arazi kullanımındaki çeşitlilik ve insan yoğunluğu ile sağlanabilir. Yayaların kendilerini güvende hissetmeme sebepleri sokakların yeterince aydınlatılmaması, kör cepheler, hızlı ve yoğun trafik ile suç oranlarının çok olması olabilir. Sokaklara açılan kapı, pencere ve balkonların olduğu sokaklar insanları daha çok güvende hissettirir [34], [1]. Bunun sebebi ise doğal gözetimin varlığıdır. Bunun yanında çıkmaz ve dar sokaklar da insan algısında suç işlemeye daha elverişli mekanlar olarak yer edindiğinden güvensizlik hissi yaratabilir. Kesintiye uğramayan, süreklilik gösteren sokak ve caddeler, kullanıcılar tarafından daha güvenli olarak algılanmaktadır ve yürümek için daha çok tercih edilmektedir [35].

\section{A. 7. Konfor}

Birey yürürken kendini rahat hissedeceği mekanlarda bulunmak ister. Bunun için de mekânın belirli fiziksel özelliklerinin olması gerekmektedir. Konfor düzeyini etkileyen başlıca fiziksel unsurlar; kaldırım genişliği, sokaklarda kullanılan döşeme malzemesinin kalitesi, iklim koşullarının olumsuz etkilerinden koruyan yardımcı elemanların varlığı, trafik düzenleme elemanlarının varlığı, sokak peyzaj 
öğeleri vb.dir. Yayalar yürüyemedikleri ya da yürümekte zorlandıkları rotaları tercih etmezler. Yolun tercih edilmesini ise coğrafyaya, kültüre ve yaşayış biçimine göre değişen konfor koşulları belirlemektedir.

Konforlu kentsel bir mekan; belirli unsurlarla sınırlandırılarak biçimlenmiş mekandır [34]. Bu sınırlar sokağın kenarındaki ağaçlar da olabilir yapıların cepheleri de olabilir. Oluşan bu biçimin konforu sağlayabilmesi için sokağın genişliği ile yapıların uzunluğu arasında uygun bir oran olması gerekmektedir. Oranın sağlandığı sokaklarda yürüyen kişi kenti oluşturan parçaları, binaları ya da yapıların cephelerini rahatlıkla kavrayabilir, açıklığın sağladığı geniş bakış açısıyla simgesel yapıları görerek sokak ağı üzerinde rotasını belirleyebilir [36].

Yapılar arasındaki kentsel boşlukların bölgenin iklimine göre tasarlanması yayaları yürümeye ve bisiklet kullanmaya teşvik etmektedir. Hava sıcaklığı, nem, rüzgar serinliği ve güneş 1sısı gibi faktörlere bağl1 olan konfor çeşididir [23].

Peyzaj öğelerinin sokaklarda kullanımı yürünebilirliği olumlu yönde etkilemektedir. Ağaçlandırılmış sokaklar sokağı ve yaya yolunu tanımlı hale getirir, trafiği yumuşatıp yayaları trafikten korur, rahatsız edici güneş ışığını engeller, sıcak havalarda serinlik verir, sokak görüntüsünü yumuşatıp düzen ve doğal güzellik verir [34], [32]. Kaldırımların bulunduğu yer iklimine uygun olacak malzeme ile kaplanması ve yaya hareketini kısıtlamayacak genişliğe sahip olması konfor düzeyini arttırır. [37], [1]. Sokaklara belli bir düzen içinde yerleştirilmesi gereken kent mobilyası, peyzaj ögesi, tabelalar, otobüs durakları gibi elemanlar da yürümeyi oldukça kolaylaştırmaktadır [1].

Tüm bu konfor koşullarına ek olarak temizlik faktörünü de ekleyebiliriz. Temiz kaldırım, cadde ve kent mobilyaları daha hijyenik bir ortam oluşmasını sağlar ve mekanın konforunu arttırır.

\section{B. ALGI / MEKANSAL ALGI}

Algı; insan davranışını belirleyen en önemli unsurlardan biridir. Bu kavram birçok anlam ve mesaj içerip ileten fiziksel dünyanın, duyular aracılı̆̆ıyla kişisel bilince aktarılması olarak da tanımlanabilir [38]. Algılama ise; tüm bu fiziksel dünyadan toplanan iletiler ile çevrenin temsil edilmesi ve anlaşılması için duyusal bilgilerin düzenlenmesi, tanımlanması ve yorumlanmasıdır. Tüm algılamaların sinir sisteminde içerdiği sinyaller bulunur. Böylece duyu organları, fiziksel veya kimyasal uyarılmaya sebep olmaktadır. Ancak alg1, bu şekilde pasif bir süreç olmaktan öte öğrenme, hafiza, beklenti ve dikkat içeren bir süreçtir [39]. Norberg-Schulz, (1966) [40]'a göre ise algılama; çevreden bilgi alma sürecini, alınan bilgilerin zihinde gruplanarak organize edilmesini ve anlamlandırılmasını kapsayan bir olgudur.

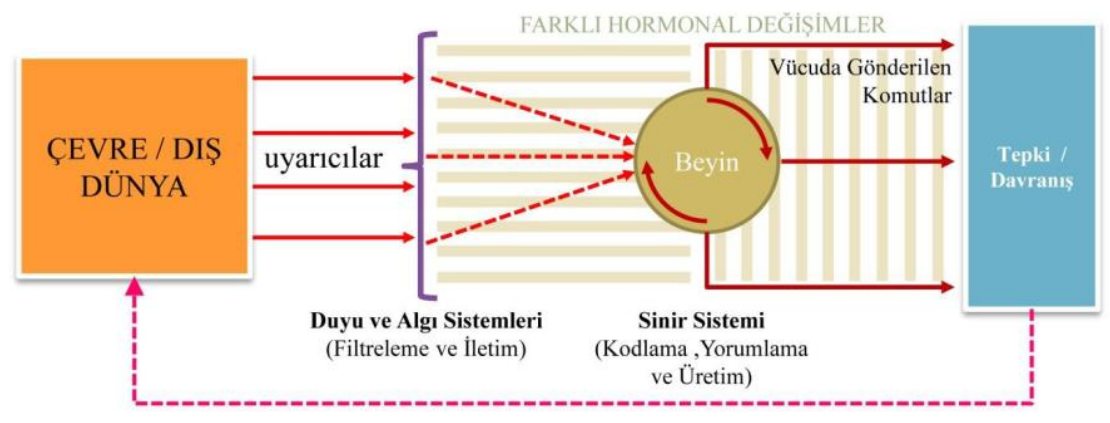

Şekil 2. Çevre-davranış dönüşüm süreci [41], [42], [43].

Şekil 2'ye bakıldığında bireyler dış dünyadaki uyarıcıları duyuları yardımı ile algılar ve beyin bu uyarıcıları örgütleyip yorumlamaya başlar. Psikolojik etkilerin oluşmasında tüm bu süreçle birlikte bireylerin kişisel özellikleri de katkı sağlamaktadır. Kişisel özelliklerden bireyin fizyolojik özelliği, sinir sistemi, hormonal yapısı ile sosyo-kültürel özellikleri, ihtiyaçları ve geçmişte edindiği deneyimleri de psikolojik etkilerin şekillenmesine katkı sağlamaktadır [44], [45]. (Ittelson, (1960) [46]'da algının kişisel bir deneyim olduğunu belirtir. Rapoport, (1977) [47]'un algılama süreci analizlerine göre ise 
fiziksel çevre uyarıcıları; kullanıcının fizyolojik ve sosyo-psikolojik özelliklerinin filtrelerden geçmesiyle, kullanıcıların her biri için farklı mekân algısı oluşmasına neden olmaktadır (Şekil 3).

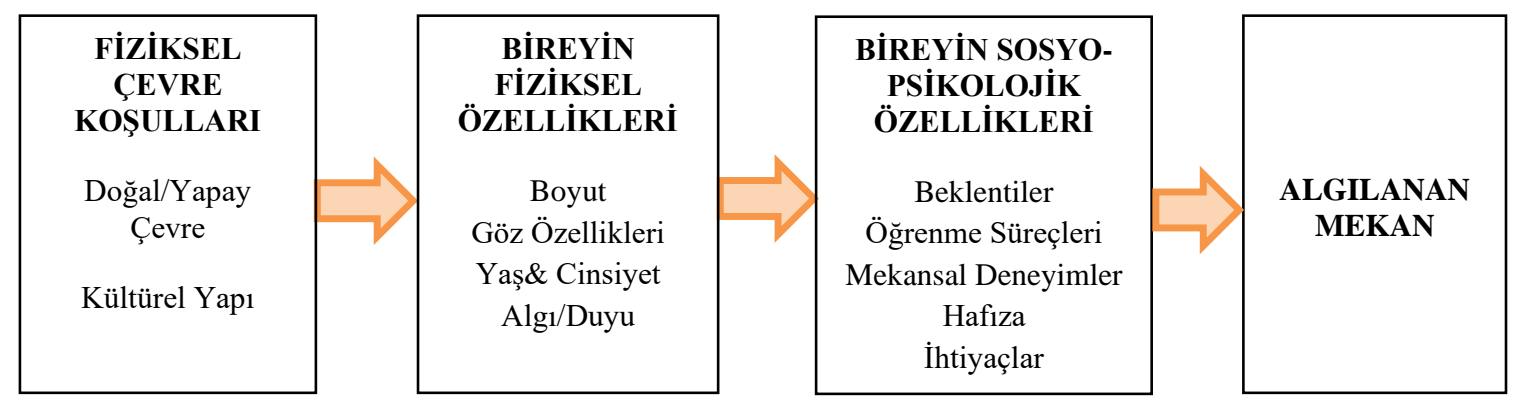

Şekil 3. Algllama süreci [47].

Yürünebilirliği önemli ölçüde etkileyen mekânın algısal niteliği Ewing vd., (2006) [11] tarafindan okunabilirlik, zihinde canlandırma, kapalılık, insan ölçeği, saydamlık ve karmaşıklık bileșenlerinden oluşmaktadır. Kevin Lynch (1960) [48], okunabilirliği "Bir çevrenin fark edilebilir ve tutarlı bir örüntü içinde organize edilebilir olmasıdır" şeklinde tanımlamıştır. Lynch'in bu tanımından okunabilirliğin çevrenin insan zihninde oluşturabildiği imge sayısı ile doğru orantılı olduğu anlaşılmaktadır [48]. O’Neill (1991), [49] için okunabilirlik, tasarlanmış öğelerin insan zihninde etkili bir imaj oluşturarak zihin haritasına katkı sağlayabilme derecesidir. Bir yerin okunabilirliğini arttırmak için; yön bulmayı kolaylaştıracak, sokakları tanımlı hale getirecek fiziksel elemanlar kullanılmaktadır [11]. Zihinde canlandırma yapılı çevrenin farklı, akılda kalan ve unutulmayan nitelikleri olarak tanımlanabilir. Tasarımda akıllıca kullanılacak unsurlar ve düzenlemeler, kullanıcılarda farklı etkilere yol açarak mekânı unutulmaz hale getirecektir [11]. Tarihi yapılar, referans noktaları, panorama ve vistaların varlığı mekana karakter kazandırarak akılda kalıcılığını arttırmaktadır. Kapalılık, sokak vd. mekânların; çevredeki bina, duvar, ağaç vb. fiziksel elemanlar ile sınırlandırılma derecesini göstermektedir. Kapalılığın kalitesini mekânı tanımlamada kullanılan dikey unsurlar ile bu unsurların arasındaki yatay boşlukların oranı belirlemektedir [11]. İnsan ölçeği, mekânı tanımlamada kullanılan fiziksel unsur boyutlarının, yapı oranlarının, kullanıcılar tarafindan kolay algılanabilir olmasını ifade etmektedir. Saydamlık, kullanıcının bulunduğu yerden, bir mekanın girişi ile mekandaki aktiviteleri görebilmesi, algılayabilmesidir. Karmaşıklık ise bir yerin görsel zenginliğini anlatırken fiziksel çevrenin çeşitliliği ile ölçülmektedir. Karmaşıklığın fazla olması kullanıcının kafasının karışmasına sebep olarak yürünebilirliği olumsuz yönde etkileyebilmektedir.

\section{MATERYAL - METOT}

\section{A. MATERYAL}

Araştırmanın materyalini Düzce il merkezi Spor Sokak ve Gaziantep Caddesi, kullanıcısı olan halk, seçilen yollar boyunca bulunan binalar ve diğer peyzaj elemanları oluşturmaktadır. Araştırma alanı, Batı Karadeniz Bölgesi, Düzce ilinde bulunmaktadır. Düzce'nin kuruluşu 12 Kasım 1999 depremi sonrasında Bolu ilinden ayrılması ile başlamıştır. En eski tarihi 15. yy. a kadar dayanmaktadır. Bitinyalılar, Roma ve Bizans, Osmanlı ve Cumhuriyet dönemi evrelerini geçirmesi sonucunda önemli tarihi kalıntılara da ev sahipliği yapmaktadır. Düzce ili İstanbul ve Ankara yol aksı üzerindeki konumu bakımından önemli bir yere sahiptir (Şekil 4). 


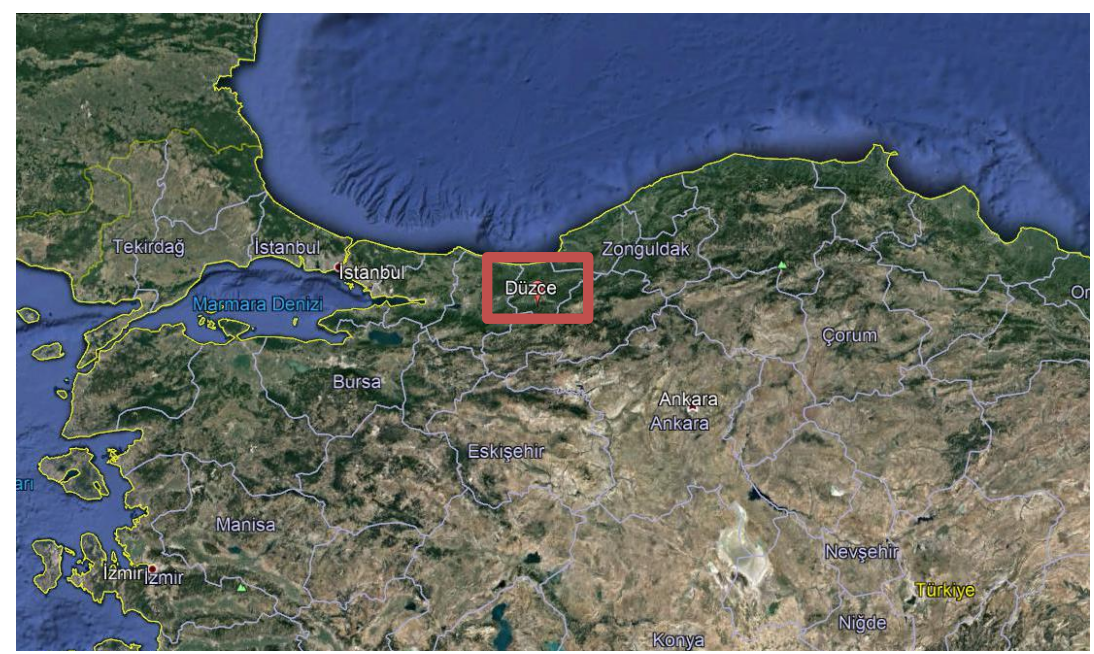

Şekil 4. Düzce ilinin çevre illere göre konumu.

Çalışma alanı olarak; Düzce Spor Sokağının sadece yayalar tarafından kullanılan bölümü ile Gaziantep Caddesinin tamamı belirlenmiştir. Spor Sokak Atatürk Meydanından başlayarak Gaziantep Caddesinin başlangıcına kadar uzanan bir sokaktır. Gaziantep Caddesi ise Spor Sokağın bitiminden Çınlar Sokağa kadar devam eden bir caddedir. Bu alan devlet kurumları, dini yapılar, kent meydanı ile önemli iş merkezlerine yakın olması sebebi ile kent merkezinin en işlek alandandır (Şekil 5), (Şekil 6). Bu bölgenin çalışma alanı olarak seçilmesinin sebebi; Düzce'nin en çok kullanılan, araç trafiğine kapalı yaya aksı olup ticaret, eğlence, hizmet gibi farklı işlevleri bir arada barındırmasıdır.

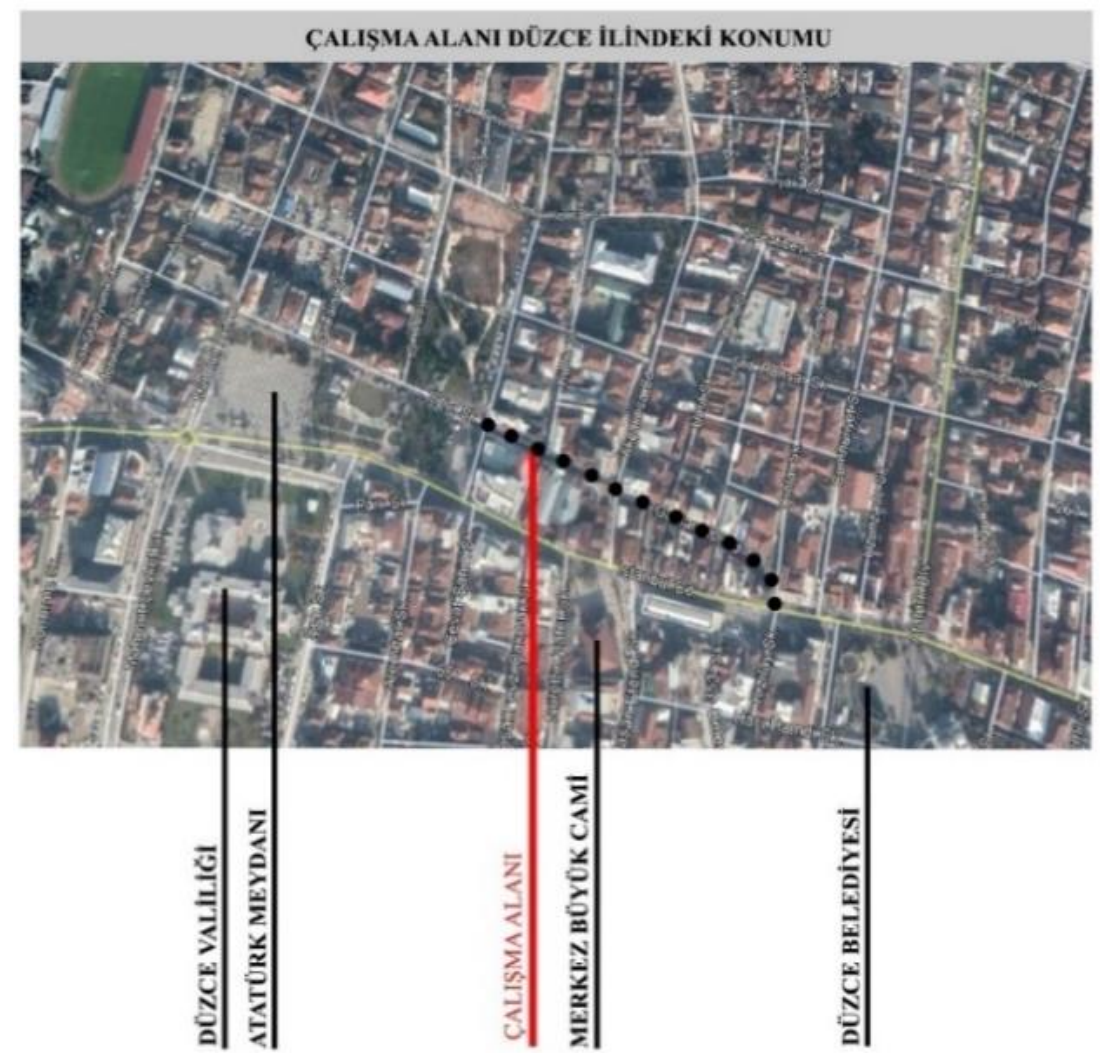

Şekil 5. Çalışma alanının Düzce il merkezindeki konumu. 


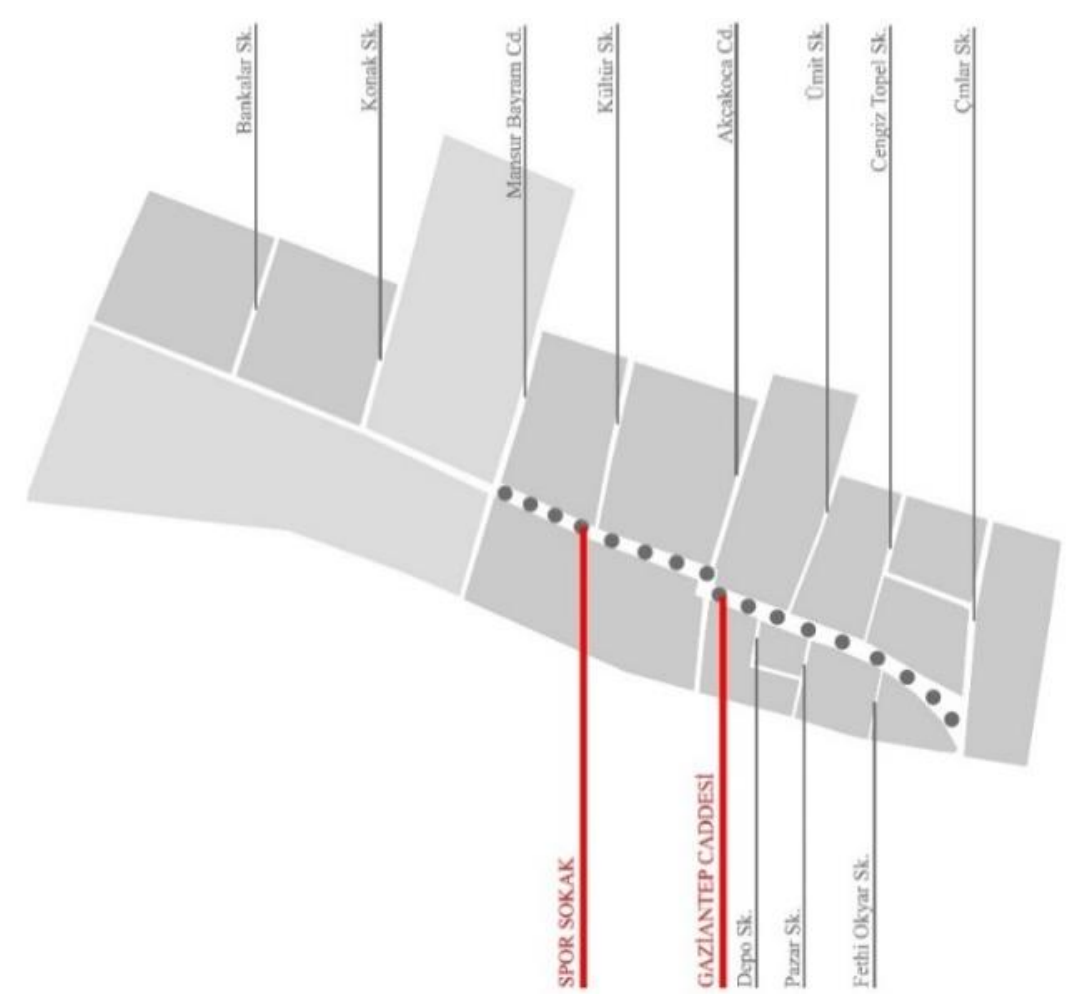

Şekil 6. Çalışma alanı çevresindeki yapı adaları ve sokaklar.

\section{B. METOT}

$\mathrm{Bu}$ çalışma kapsamında nitel ve nicel veriler üzerinden yürünebilirlik olgusu incelenmektedir. İlk aşamada Düzce ili merkez ilçesinde seçilen Spor Sokak ve Gaziantep Caddesinde nitel veri elde edilecek anket yöntemi uygulanmıştır. 2020 Ocak ayında uygulanmaya başlanmış ve 2 ay gibi bir sürede tamamlanmıştır. Günün erken saatlerinde başlanarak akşam saatlerine kadar devam eden anketler caddeyi kullananlar ile iş yeri sahiplerine uygulanmıştır. Anket örneklem grubu, sokakta bulunan rastgele seçilen, ankete katılmayı kabul eden kişilere uygulanmıştır. Yüz yüze, soru-cevap yapılan anketlere ek dükkan sahiplerine dağıtılıp cevaplayanlardan sonraki günlerde toplanarak değerlendirmeye alınan anketler de olmuştur. Toplamda 130 kişiye uygulanan anketlerde ankete katılan kişiler belirlenen cinsiyet ve yaş kriterlerinin sayıca birbirine yakın olacak şekilde seçilmiştir. Uygulanan anket verileri SPSS (Statistical Package for the Social Sciences) programına aktarılarak uzman desteği ile analizler yapılmıştır. SPSS programında güvenilirlik ölçeği olarak "Cron-bach alfa" kullanılmıştır. Cron-bach tarafından 1951 yılında geliştirilen yöntem, anket maddeleri 1-3, 1-4, 1-5 şeklinde sıralı (ordinal) puanlama yapıldığında kullanılan bir yöntemdir. Cronbach alfa katsayısı, ölçekte yer alan k maddenin varyansları toplamının genel varyansa oranlanması ile bulunmaktadır[50]. İkinci aşamada ise nicel verileri elde edebilmek için çalışma alanına gidilerek Spor Sokak ve Gaziantep Caddesi boyunca bulunan mekanların tüm zemin kat cepheleri fotoğraflanmış bu sayede zemin kat kullanım grafikleri elde edilmiştir. Aynı zamanda sabah saat: 10.00, öğle: 14.00, akşam: 18.00, gece: 22.00 ' da beş gözlem noktasından sokaklar fotoğraflanarak kullanıcı yoğunluğu gözlemlenmiştir. Çalışma alanındaki fiziki unsurların (sokak lambaları, çöp kutuları, mazgallar, güvenlik kameraları ve ağaçlar) konumları yerinde gözlem yapıldıktan sonra GIS (Geographic Information System) yazılımı olan ArcGIS (10.7) programında toplanan veriler aktarılmış ve mekânsal analizler yapılmıştır. 


\section{BULGULAR}

\section{A. NITEL VERILER}

\section{A. 1. Anket Bulguları}

Çalışmanın örneklem yapısı Düzce'de yaşayan 130 kişiden oluşmaktadır. Bu yapının sosyo-demografik özelliklerine bakıldığında \%53'ünün erkeklerden, \%47'sinin kadınlardan; \%27'sinin 18-25 yaş arası, \%46'sının 26-40 yaş arası, \%27'sinin 41 yaş ve üzeri bireylerden; \%2'sinin ilkokul, \%7'sinin ortaokul, \%25'inin lise, \%6'sinın ön lisans, \%42'sinin lisans, \%18'inin lisansüstü mezunlarından; \%2'sinin emekli, \%10'unun memur, \%32'sinin serbest meslek, \%19'unun öğrenci, \%18'inin eğitimci, \%13'ünün mimar/mühendis, \%6'sının işçi olduğu bireylerden; \%67'sinin Merkezde, \%11'inin Konuralp'te, \%17'sinin Kalıcı Konutlarda, \%5'inin Merkez dışında yaşayanlardan; \%41'inin Düzce'de 0-10 yıl, $\% 21$ 'inin 11-20 yıl, \%14'ünün 21-30 y1l, \%12'sinin 31-40 y1l arasında, \%12'sinin 41 y1l ve üzerinde yaşayanlardan; \%24'ünün sabah (07.00-09.00), \%23'ünün öğle (11.30-14.00), \%53'ünün akşam (16.0020.00) saatlerinde alanı kullananlardan ve alanı \%23'ünün iş, \%36'sının alışveriş, \%7'sinin eğlence, \%24'ünün yeme-içme, \%2'sinin kestirme olarak, \%8'inin diğer sebepler için kullananlardan oluştuğu Tablo 1'de görülmektedir.

Tablo 1. Örnekleme iliş̧kin sosyo-demografik yapı analizi.

\begin{tabular}{|c|c|c|}
\hline \multicolumn{2}{|c|}{ Katılımcıların Özellikleri } & $\%$ \\
\hline \multirow{2}{*}{ Cinsiyet } & Kadın & 47 \\
\hline & Erkek & 53 \\
\hline \multirow{3}{*}{ Yaş } & 18-25yaş arası & 27 \\
\hline & 26-40yaş arası & 46 \\
\hline & 41 yaş ve üzeri & 27 \\
\hline \multirow{6}{*}{ Öğrenim Seviyesi } & İlkokul & 2 \\
\hline & Ortaöğretim & 7 \\
\hline & Lise & 25 \\
\hline & Ön lisans & 6 \\
\hline & Lisans & 42 \\
\hline & Lisansüstü & 18 \\
\hline \multirow{7}{*}{ Meslek Grupları } & Emekli & 2 \\
\hline & Memur & 10 \\
\hline & Serbest Meslek & 32 \\
\hline & Öğrenci & 19 \\
\hline & Eğitim & 18 \\
\hline & Mimar/Mühendis & 13 \\
\hline & İşçi & 6 \\
\hline \multirow{4}{*}{$\begin{array}{c}\text { Düzce'de Yaşanılan } \\
\text { Yer }\end{array}$} & Merkez & 67 \\
\hline & Konuralp & 11 \\
\hline & Kalıcı Konutlar & 17 \\
\hline & Merkez D1ş1 & 5 \\
\hline \multirow{5}{*}{$\begin{array}{c}\text { Düzce'de Yaşanılan } \\
\text { Süre }\end{array}$} & $0-10$ yil & 41 \\
\hline & $11-20 \mathrm{y} 1 \mathrm{l}$ & 21 \\
\hline & 21-30 y1l & 14 \\
\hline & $31-40$ y1l & 12 \\
\hline & 41 yıl ve üzeri & 12 \\
\hline \multirow{3}{*}{$\begin{array}{l}\text { Sokakların Kullanıldığı } \\
\text { Saatler }\end{array}$} & Sabah (07.00-09.00) & 24 \\
\hline & Öğle (11.30-14.00) & 23 \\
\hline & Akşam (16.00-20.00) & 53 \\
\hline \multirow{6}{*}{$\begin{array}{l}\text { Sokakların Kullanılma } \\
\text { Sebepleri }\end{array}$} & İş & 23 \\
\hline & Alışveriş & 36 \\
\hline & Eğlence & 7 \\
\hline & Yeme-İçme & 24 \\
\hline & Kestirme olması & 2 \\
\hline & Diğer & 8 \\
\hline
\end{tabular}


Düzce kent merkezindeki sokakları kullanıcıların nasıl tanımladığını belirlemek üzere frekans analizi uygulanmıştır. Kullanıcıların alanı tanımlaması için 12 adet kriter değerlendirmeye alınmıştır. Frekans analizi sonucunda, Düzce kent merkezindeki sokakları tanımlamada kullanılan kriterler; erişilmez, cansız, karışık, tehlikeli, güvenilmez, kimliksiz, çeşitli, havadar, konforlu, zevkli, modern ve bakımlı olarak sıralanmaktadır (Tablo 2). Alanı tanımlamada kullanılan ölçeğin güvenilirliğinin test edilmesi sonucunda ise cronbach's alpha değerinin \%95 olduğu belirlenmiştir ve ölçek oldukça güvenilir olarak bulunmuştur. Analiz sonuçları aşağıda karşılaştırmalı olarak verilmiştir (Şekil 7), (Şekil 8), (Şekil 9).

Tablo 2. Mekansal algl frekans analizi.

\begin{tabular}{cc}
\hline Tutum & $\begin{array}{c}\text { Aritmetik } \\
\text { Ortalama }\end{array}$ \\
\hline Canlı-Cansız & 4,67 \\
\hline Çeşitli-Tekdüze & 3,98 \\
\hline Akılda Kalıc1-Kimliksiz & 4,19 \\
\hline Anlaşılır-Karışık & 4,32 \\
\hline Bakıml1-Bakımsız & 3,41 \\
\hline Havadar-Bunaltıcı & 3,95 \\
\hline Güvenli-Tehlikeli & 4,27 \\
\hline Konforlu-Rahatsız & 3,67 \\
\hline Modern-Eski Moda & 3,45 \\
\hline Emniyetli-Güvenilmez & 4,27 \\
\hline Zevkli-Sıkıcı & 3,57 \\
\hline Bağlantıl1-Erişilmez & 5,35 \\
\hline
\end{tabular}

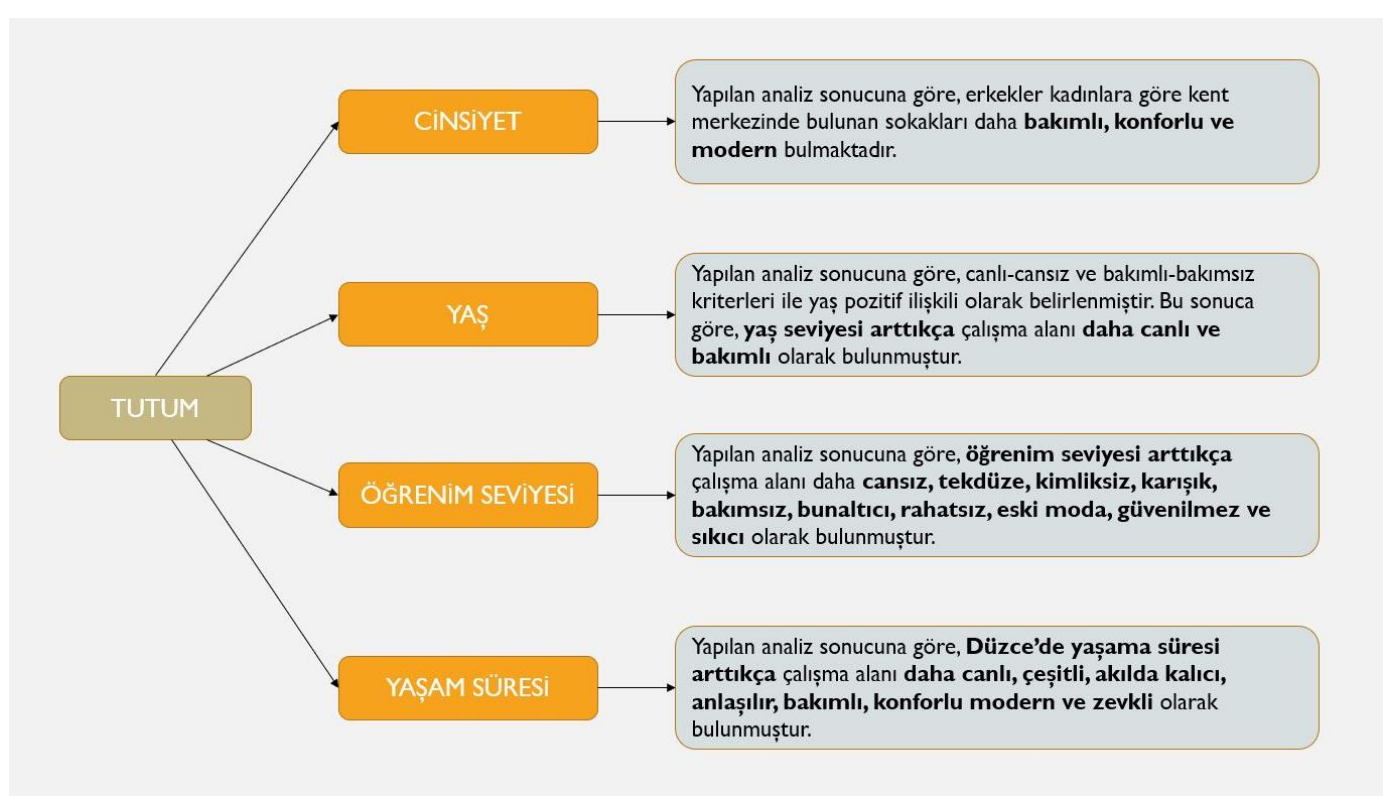

Şekil 7. Belirlenen tutumların cinsiyet, yaş, öğrenim seviyesi, yaşam süresine göre değerlendirilmesi. 


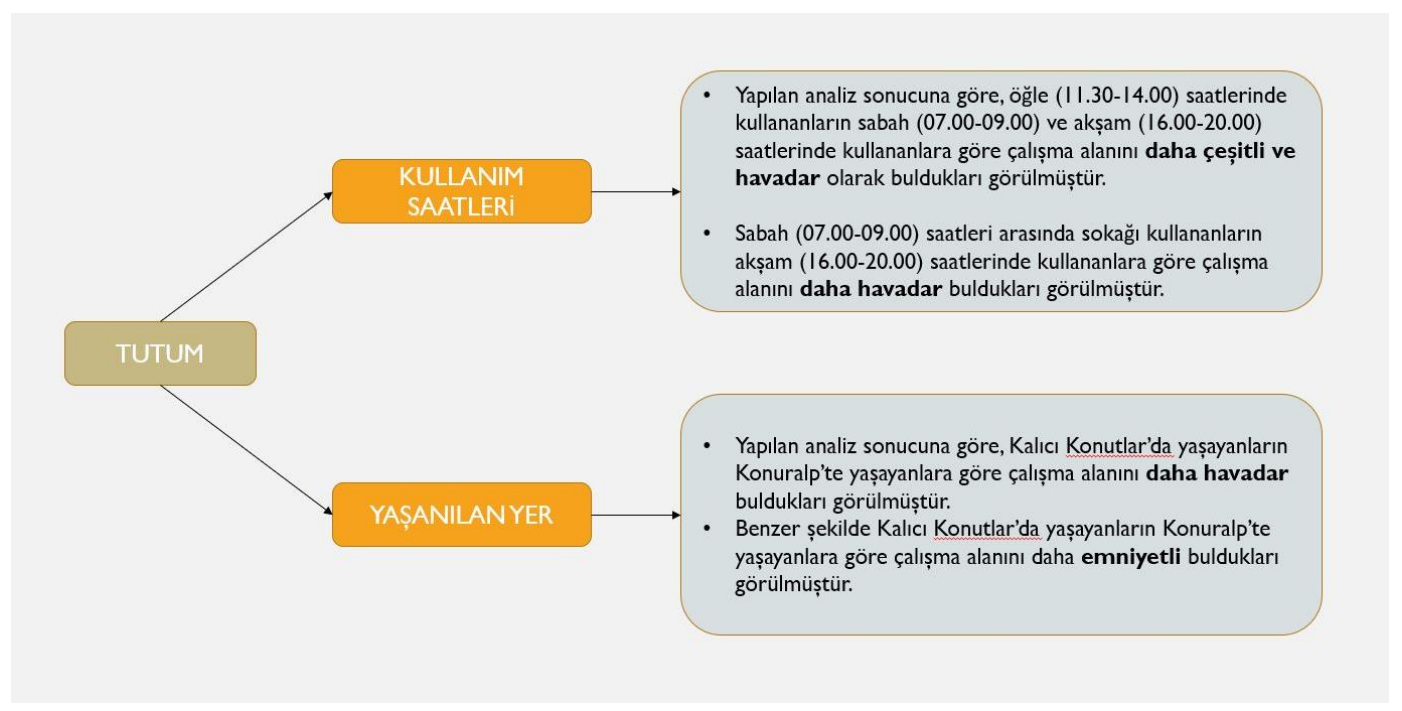

Şekil 8. Belirlenen tutumların kullanım saatleri ve yaşanılan yere göre değerlendirilmesi.

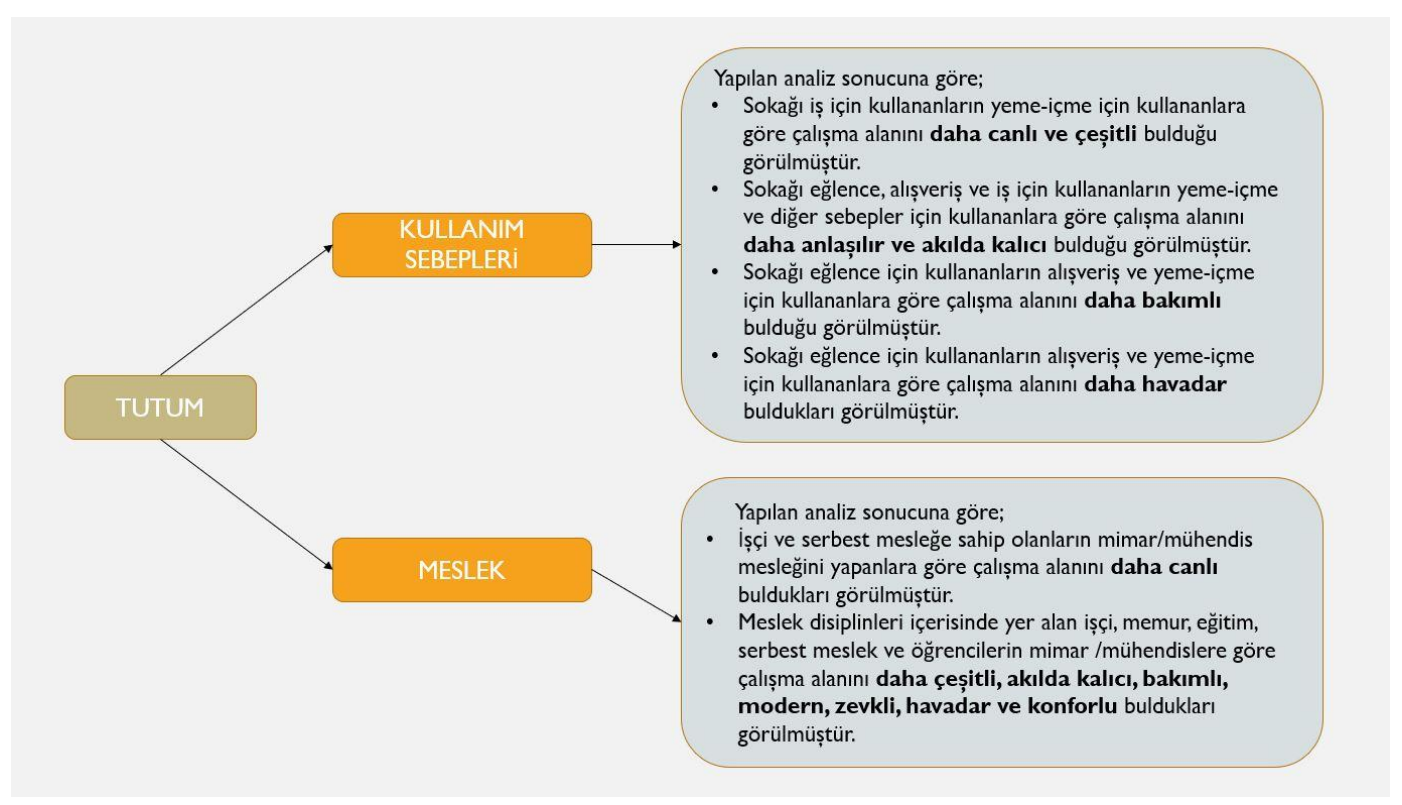

Şekil 9. Belirlenen tutumların kullanım sebepleri ve mesleğe yere göre değerlendirilmesi.

\section{B. NICEL VERILER}

\section{B. 1. ArcGIS Bulguları}

Çalışmanın bu bölümünde alandaki yürünebilirlik ve mekânsal algıyı etkileyen unsurlar saha çalışması ve ArcGIS 10.7 programı ile analiz edilecektir. Alanda yapılan gözlem ve fotoğraflama çalışmalarının sonuçları ArcGIS 10.7 programına aktarılmıştır. Bu bağlamda gözlem yapılan unsurlar; mekanların zemin kat işlevleri, kat sayıları, saatlere göre kullanıcı yoğunluğu, sokak lambaları/çöp kutuları/drenaj elemanları/güvenlik kameraları konum, tür ve sayıları olmuştur.

\section{B. 1. 1. Bağlam}

“Yürünebilirlik ve Mekânsal Alg1 Arasındaki İlişkisinin İrdelenmesi: Düzce Örneği” başlıklı çalışmada amaç; Düzce ilinin belirlenen çalışma alanında yürünebilirlik değerinin nitel ve nicel veriler yardımı ile ölçülmesidir. Bu amaç doğrultusunda kent merkezinde yayalar tarafından en sık kullanılan iki ana yaya 
yolu çalışma alanı olarak belirlenmiştir. Seçilen yaya yollarından biri Spor Sokak diğeri ise Gaziantep Caddesidir. Spor sokak hem taşıt yolu hem de yaya yolu olmak üzere iki kullanıma hizmet etmektedir. Çalışmaya ise sadece yaya yolu olarak kullanılan kısmı dahil edilmiştir. Gaziantep Caddesi Spor Sokağın taşıt yolu olarak kullanılan Akçakoca Caddesinin kestiği yerden başlayarak Düzce ilinde ana taşıt yolu olarak kullanılan İstanbul Caddesine kadar uzanır. Spor Sokak ve Gaziantep Caddesi kuzeyde Kültür Sokak, Ümit Sokak, Cengiz Topel Sokaktan; güneyde Depo Sokak ve Pazar Sokaktan; Gaziantep Caddesinin bitiminde Çınlar Sokaktan beslenir.

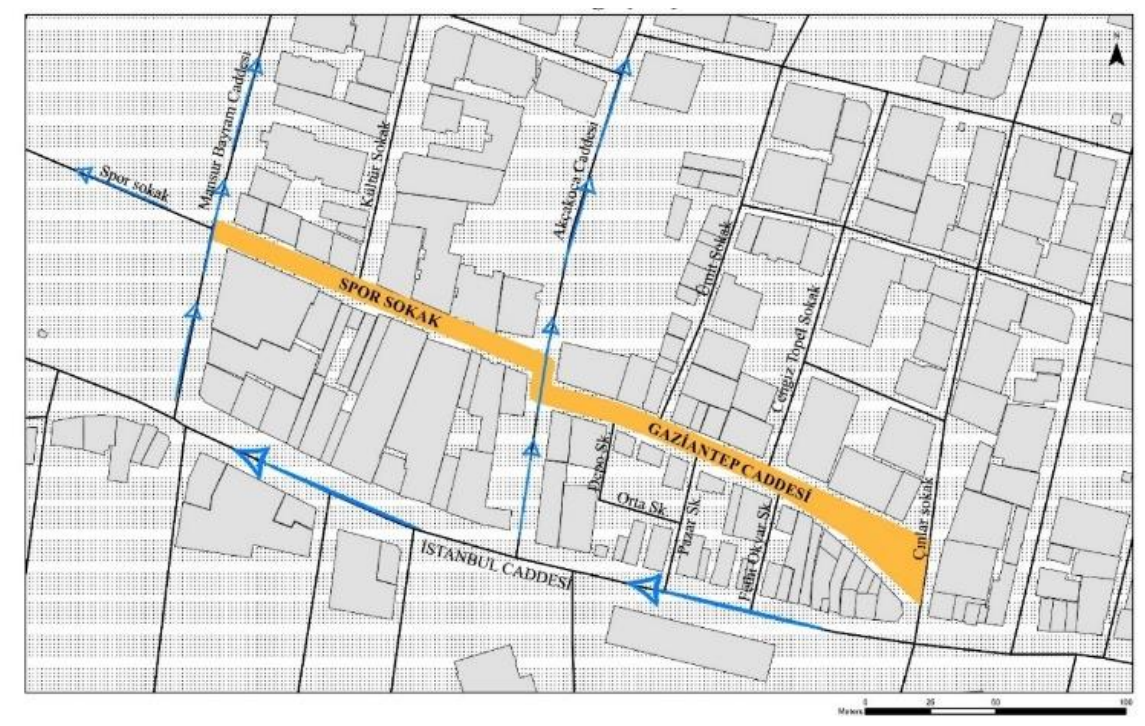

Şekil 10. Çalışma alanı sınırları ve alanın yakınında bulunan taşıt yolları.

Şekil 5 ve Şekil 10'da görüldüğü üzere çalışma alanı ilin merkezi ve en işlek bölgesinde olması, kamusal mekanlara yakın olması (belediye binası, merkez büyük cami, Atatürk meydanı, valilik binası) ona kimlik kazandırmıştır. Kazandığı bu kimlik sayesinde yürünebilirlik değerleri olumlu yönde etkilenmiştir.

\section{B. 1. 2. Erișilebilirlik}

Çalışma alanı yaklaşık 300m uzunluğunda, Spor Sokak $7 \mathrm{~m}$ genişliğinde başlayıp $8 \mathrm{~m}$ genişliğinde sonlanmış, Gaziantep Caddesi ise 9m genişliğinde başlayarak $18 \mathrm{~m}$ genişliğinde sonlanmıştır (Şekil 11). Çevresinde bulunan yapı adaları küçüktür. Çalışma alanının etrafına genel olarak bakıldığında ise ızgara sisteme sahip bir sokak dokusu bulunmaktadır. Bu sayede geçirgen ve erişilebilir olduğunu söylemek mümkündür. Aynı zamanda bu alan eğimi olmayan eşit erişilebilir bir yapıdadır. Spor Sokak ve Gaziantep Caddesini keskin bir şekilde ayıran taşıt yolu (Akçakoca Caddesi) erişilebilirlik düzeyini düşürse de trafiğin yavaş akmasından dolayı çok fazla etkili olmamaktadır (Şekil 11).

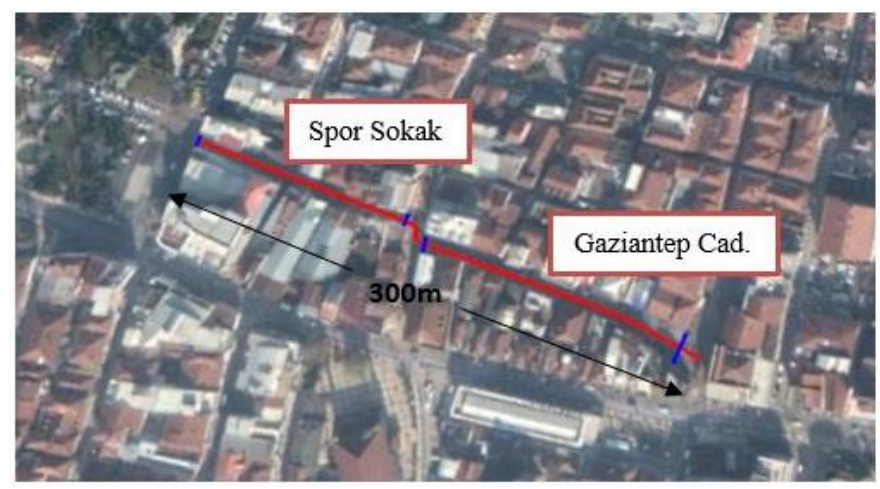

Şekil 11. Çalışma alanı yol uzunluğu ve sokak genişliği. 


\section{B. 1. 3. Çeşitlilik}

Yaya yollarında zemin katlar kullanıcıların en çok etkileşimde bulunduğu mekanlardır. Spor Sokak ve Gaziantep Caddesinde bulunan tüm zemin katlardaki mekan işlevleri gözlemlenmiştir. Bu çalışma sonucunda; 9 telefon ve elektronik eşya, 6 kozmetik ürünler, 3 ayakkabı, 3 aksesuar ürünleri, 2 iç çamaşır, 2 spor ürünleri, 1 beyaz eşya, 1 müzik aletleri, 1 gümüş, 1 ziraat ürünleri, satan mekanlar; 18 restoran, 16 butik, 4 büfe, 1 kafe, 2 eczane, 1 kırtasiye, 1 pastac1, 1 kuaför, 1 pub, 1 şarküteri, 1 saatçi, 1 fotoğrafçı, 1 hırdavatçı bulunmaktadır. Ayrıca Spor Sokakta 5 pasaj bulunur. Bunlardan 2 tanesi İstanbul Caddesi ile bağlantılı olup içinde ağırlıklı olarak alışveriş mekanları bulundurur. Mekanları işlevlerine göre; alışveriş, yemek, sağlık, eğlence ve diğer hizmet mekanları olarak gruplandırarak yüzdelerine baktığımızda her iki aks genelinde $\% 71$ alışveriş, $\% 23$ yemek, $\% 3$ sağlık, \%1 eğlence ve \%2 diğer hizmet mekanları yüzdeleri ile en çok alışveriş mekanlarının bulunduğunu görmekteyiz (Şekil 12).

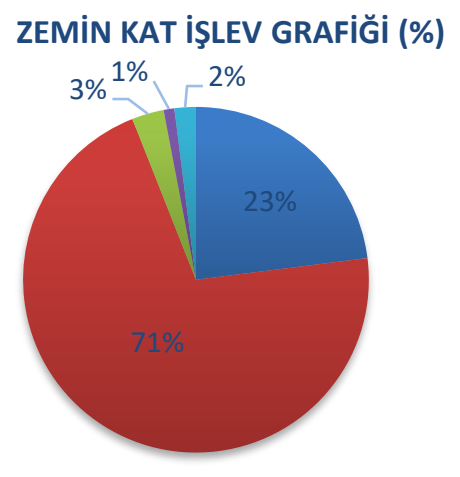

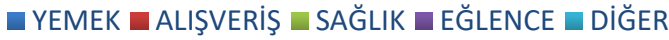

Şekil 12. Spor Sokak ve Gaziantep Caddesi zemin kat işlev dă̆glımı (yüzde olarak).

\section{B. 1. 4. Ölçek}

Kat sayısı çevresel algıyı etkileyen en önemli unsurlardan biridir. Yapı kat adedi arttıkça mekandaki kapalılık hissi artar. Spor Sokak ve Gaziantep Caddesi aksında bulunan yapı kat analizine bakıldığında en çok 5 katlı yapıların bulunduğu görülmektedir (Şekil 13), (Şekil 14). Bu kat adetleri oldukça yaya ölçeğinde olup kullanıcıyı ezmeyecek boyutlardadır. Alandaki sınırlama ve kapalılık hissini vermeye yeterlidir.

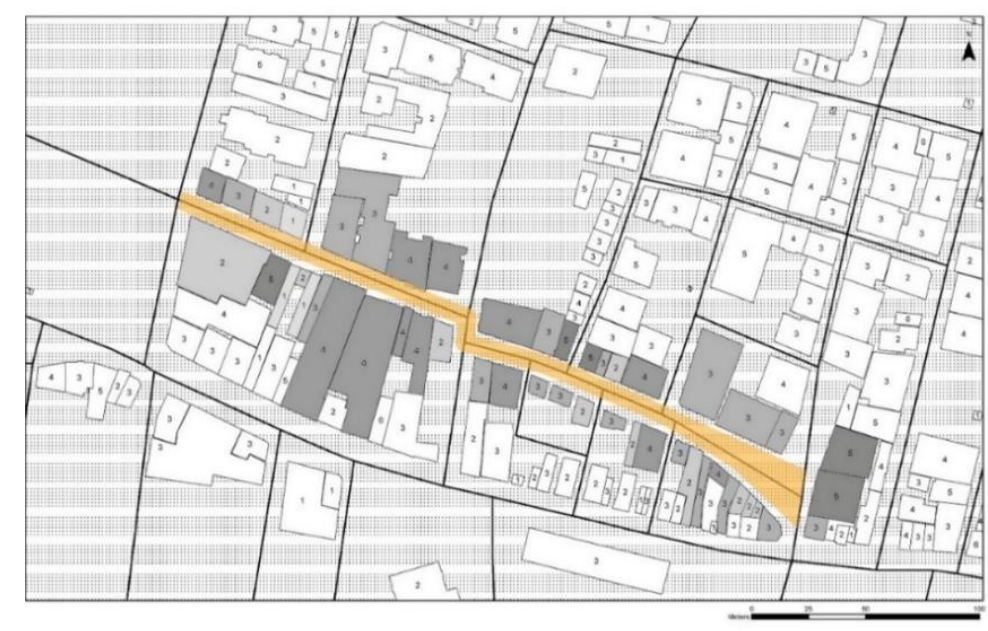

Şekil 13. Kat adedi analizi. 


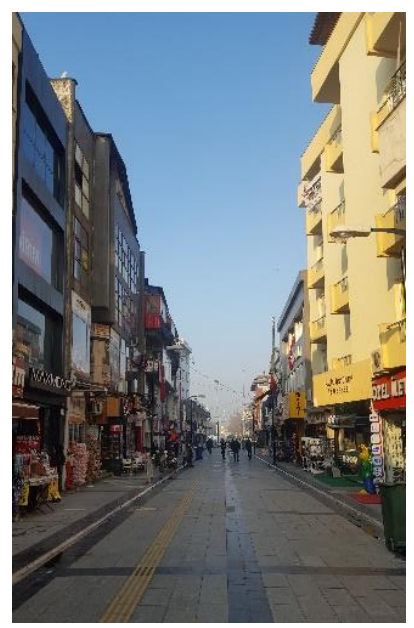

(a)

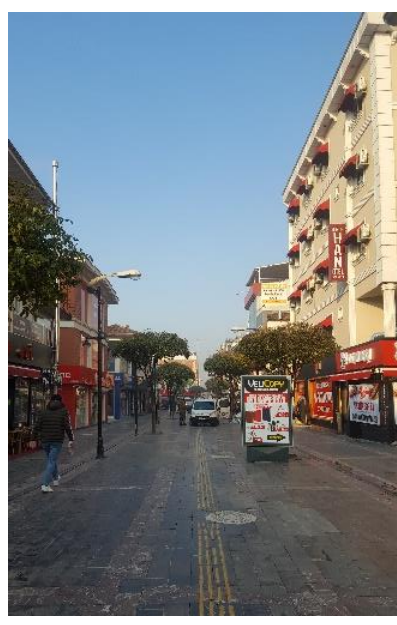

(b)

Şekil 14. (a) Spor Sokak Görünüm, (b) Gaziantep Caddesi Görünüm.

\section{B. 1. 5. Yoğunluk}

Saha çalışmasında yapılan gözlem sonucunda; bu yaya yollarının genel olarak bakıldığında Şekil 15'te işaretlenen bölgeleri daha yoğun bir şekilde kullanıldığı görülmüştür. Spor Sokak ve Gaziantep Caddesinin merkez noktalarının daha yoğun olmasının sebebi; buralardaki mekanlarının işlevlerinin daha çeşitli olmasıyla birlikte beklemelerin artmasından, giriş çıkışlara göre daha dar alanların oluşmasından kaynaklı yoğunluğun arttığı söylenebilir. İki yolun kesiştikleri Akçakoca Caddesinin önceki açıklanan yerlere göre daha yoğun olmasını bu caddenin taşıt yolu olması ve iki yol aksındaki yaya akışını keskin bir şekilde kesmesidir. Yayalar burada karşıdan karşıya geçerken taşıtları beklemekte beklerken de o bölgelerde yoğunluğun artmasına sebep olmaktadırlar.

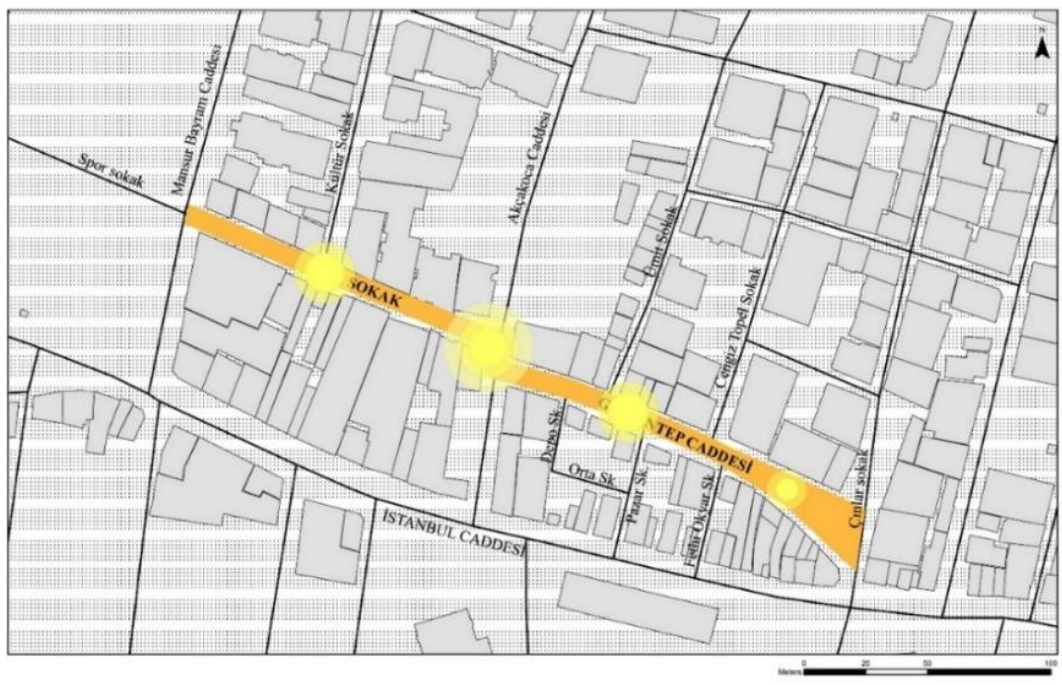

Şekil 15. Bölgelere Göre Yoğunluk Analizi. 
Tablo 3. Spor Sokak ve Gaziantep Caddesinde saatlere göre yaya yoğunluk analizi.

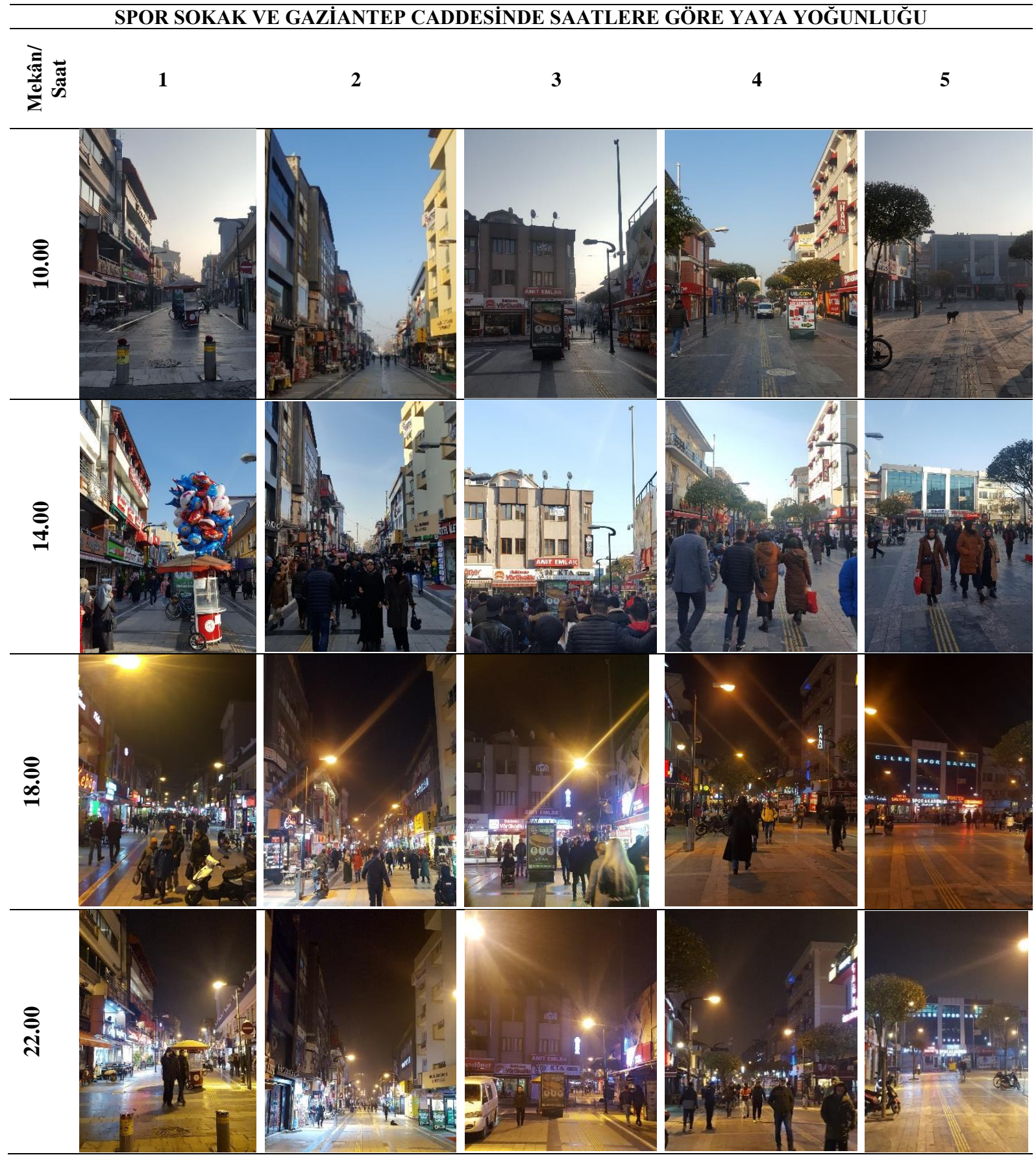

Genel değerlendirmenin sonrasında alanda saatlere göre yaya yoğunluğunu analiz etmek için gözlem ve fotoğraflama çalışmaları yapılmıştır. Sabah, öğle, akşam ve gece değerlendirmesi için saat 10:00, 14:00, 16:00 ve 22:00'de aynı gözlem noktalarından farklı açılardan fotoğraflar çekilmiştir (Tablo 3). Bu çalışmanın sonucunda ise; günün sabah saatlerinde sokakların oldukça sakin ve boş olduğu, öğle saatinden akşam saatine kadar en yoğun kullanıcının bulunduğu, akşam saatlerinde ise bunun azalarak devam ettiği görülmüştür. Gece saatlerinde; sabah saatlerine benzer bir durum oluşmaktadır. Sokaklar yoğun öğle ve akşam saatlerinden sonra sakinliğe bürünmüştür.

\section{B. 1. 6. Güvenlik}

Güvenlik faktörü mekanın kullanıcılarını orada güvende hissetmeleri açısından oldukça önemli bir faktördür. Kullanıcıların kendilerini güvende hissettiği mekanlarda bulunma isteği ise güvenilirliğin 
artması ile doğru orantılıdır. Bu bağlamda sokaktaki güvenlik etmeni güvenlik kameraları ve sokak lambaları analizi ile irdelenmiştir.

Belediyenin sağladığı güvenlik kameraları Spor sokağın başında ve sonunda yani Gaziantep Caddesi ile kesiştiği noktalarda bulunmaktadır (Şekil 16). Ayrıca alanda her dükkânın kendine ait güvenlik kamerası da bulunmaktadır. Anket yapma aşamasında alanı sürekli kullanan esnafların güvenlik kameralarının konulmasından sonra olayların azaldığını belirttiği görülmüştür. $\mathrm{Bu}$ da en başta bahsedilen cümleleri destekler durumda bir cevap olmuştur.

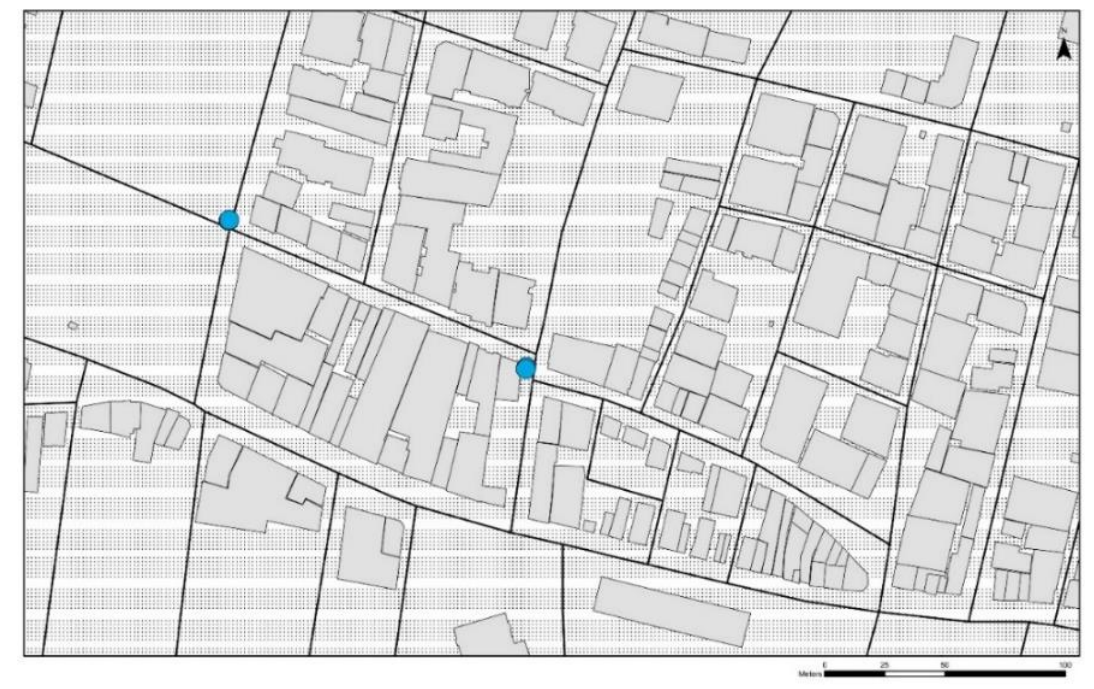

Şekil 16. Güvenlik Kamerası Konumları Analizi.

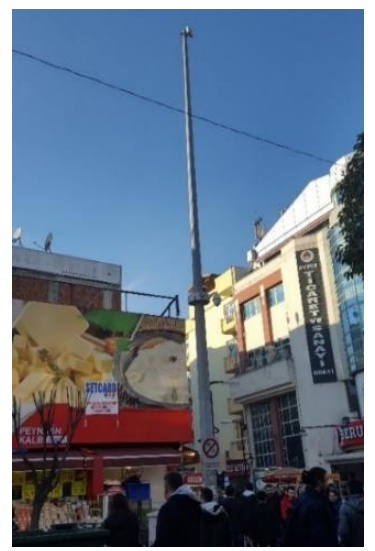

(a)

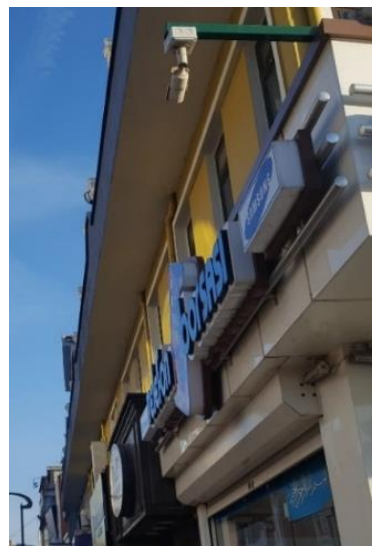

(b)

Şekil 17. (a) Belediye tarafindan konulan mobese kameraları, (b) Dükkan sahiplerinin şahsi güvenlik kameralarl.

Aydınlatma mekanların algılanmasında görünebilirliği etkilediği için önemli bir faktördür. Aynı zamanda insanlar karanlık mekanların daha az güvenilir olduğunu düşündükleri için bu alanlarda yürümekten kaçınmaktadırlar. Bu bağlamda çalışma alanındaki sokak lambalarının konumları, sıklığı ve türleri incelenmiştir. İnceleme sonucunda Spor sokağın başında ve Gaziantep caddesinin bitiminde büyük spot lambaların bulunduğu görülmektedir. Sokak ve cadde boyunca belirli aralıklarla sokak lambalarının konumlandırıldığı, Gaziantep Caddesinde ise bunlara ek olarak ara sokakların aydınlatılması için konulan küçük spot lambaların yer aldığı görülmektedir (Şekil 18). 


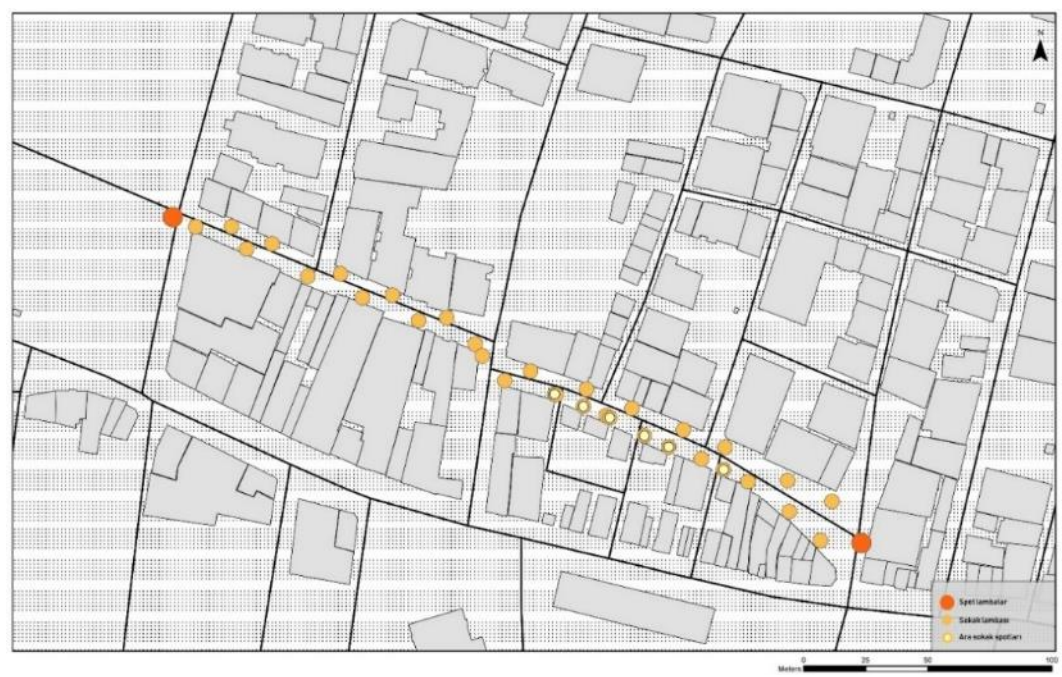

Şekil 18. Sokak lambası konumları ve türleri analizi.

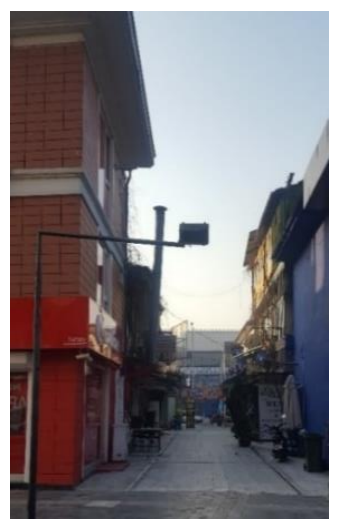

(a)

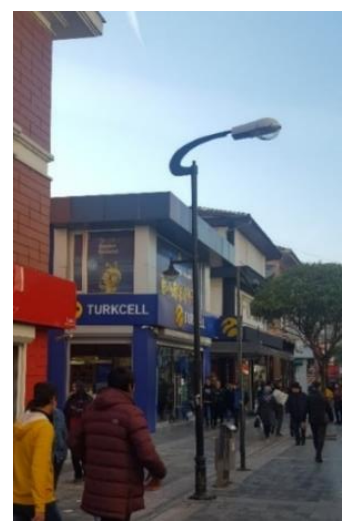

(b)

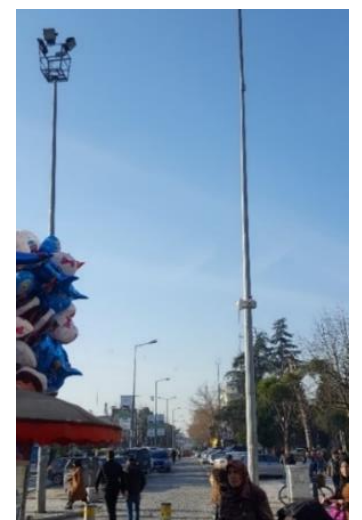

(c)

Şekil 19. (a) Gaziantep Caddesindeki ara sokakların aydınlatılması için konulan spot lambalar, (b) Sokak lambaları, (c) Sokak başlarındaki büyük spotlar.

\section{B. 1. 7. Konfor}

Çalışma alanındaki konfor, çöp kutuları, peyzaj ve zemin döşemesi ile yağmur suyu drenajı analiz edilerek değerlendirilmiştir. Alandaki çöp kutusu analizine baktığımızda; yine Gaziantep Caddesinin başında ve sonunda büyük çöp konteynerlarının olduğu ve sabit küçük çöp kutularının konumlandırıldığg görülmektedir (Şekil 20). Bununla birlikte bu sokak ve caddenin gün içerisinde belediye işçileri tarafından süpürüldügü gözlenmiştir. Çöp kutuları aydınlatma ve küçük spot ışıklarının hemen yanında ve sokakların kenarlarında konumlandırıldığından yürümeye engel teşkil etmemektedirler. 


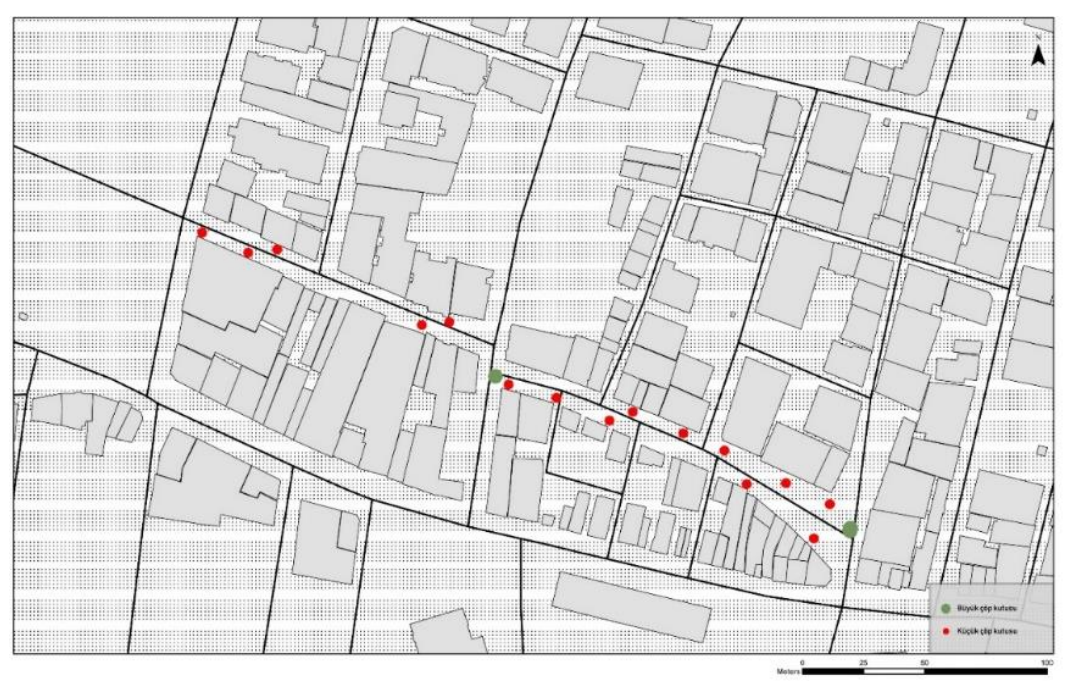

Şekil 20. Çöp kutusu konumlarl ve büyüklükleri analizi.

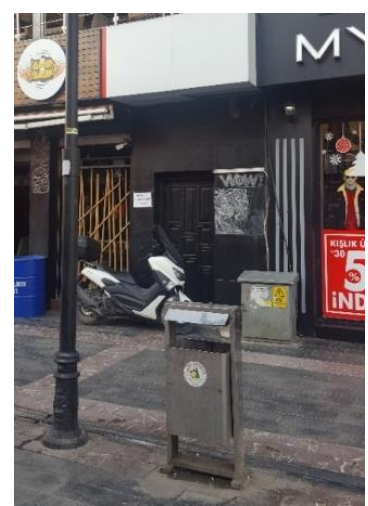

(a)

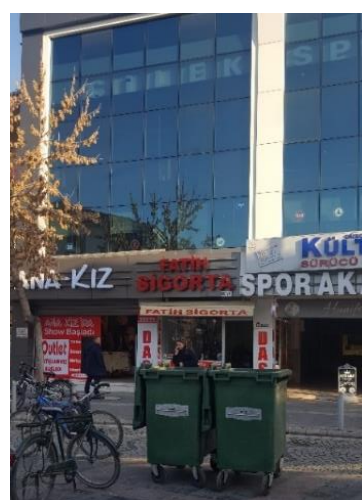

(b)

Şekil 21. (a) Küçük çöp kutuları, (b) Sokak başlarındaki büyük çöp konteynerları.

Drenaj, aşırı yağmur ve kar yağışı durumlarında suyun sokaklardan uzaklaştırılması açısından önemlidir. Drenaj unsuru olan mazgallar alanda incelendiğinde; Spor Sokağın başı ile ortasındaki yan yolla birleştiği bölgede ve Gaziantep Caddesinin başında daha büyük ebatlarda mazgal kullanıldığı görülmektedir. Bu mazgallara ek olarak sokak lambaları, çöp kutuları gibi belirli olmayan aralıklarla daha küçük ebatlarda mazgallar konumlandırılmıştır. Su yollarının sonlarında bulunan delikler de drenaja katkıda bulunmaktadır. Fakat genel olarak bakıldığından su yollarının ve deliklerin sigara izmariti gibi unsurlarla dolmuş olduğu gözlemlenmiştir (Şekil 22).

Çalışma alanında yapılan anketler sonucunda insanların en çok şikayetçi oldukları durumun yağmur veya kar yağdığında sokaklarda kullanılan döşeme malzemesinin altında biriken suyun sıçraması olduğu sonucuna varılmıştır. Bu hem kaplama malzemesinin işçiliğinin iyi yapılamayışından hem de suyun alandan uzaklaştırılmasının yeterli olmayışından kaynaklanmaktadır (Şekil 23). 


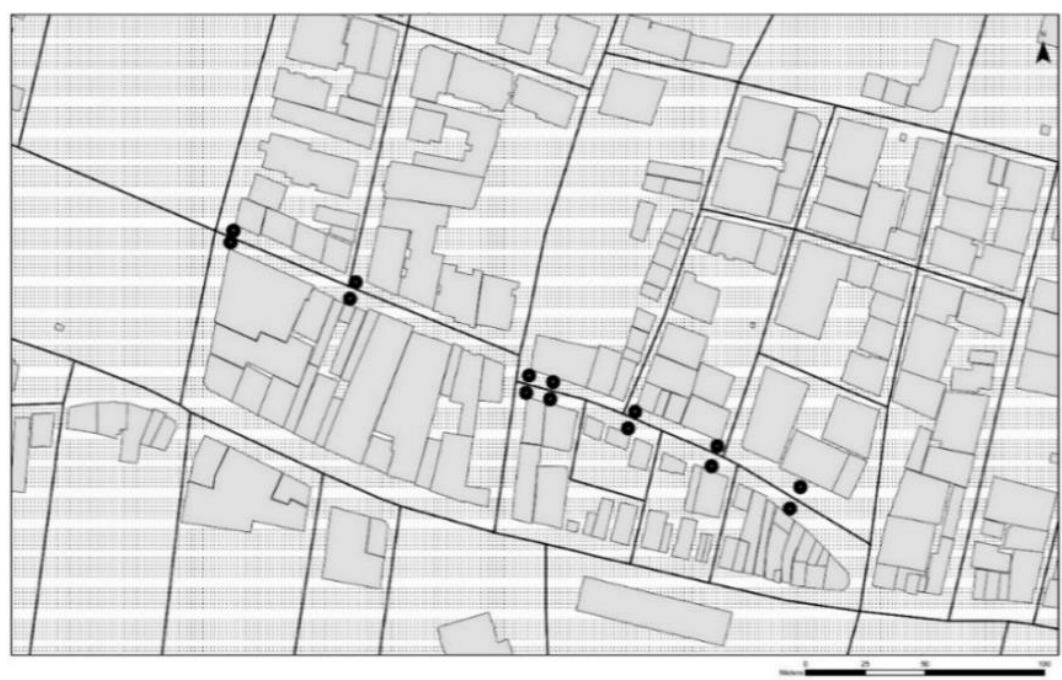

Şekil 22. Mazgal Konumları Analizi.

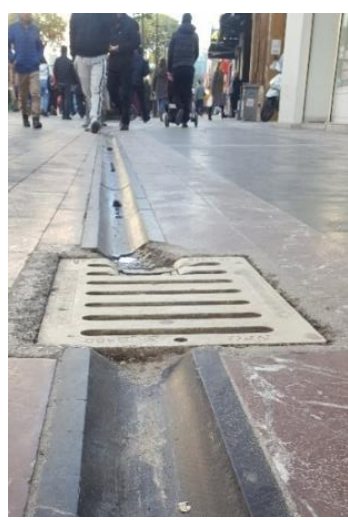

(a)

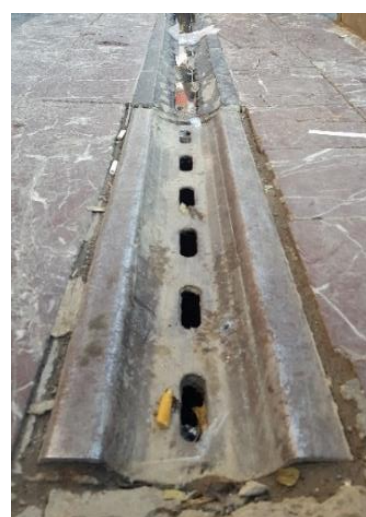

(b)

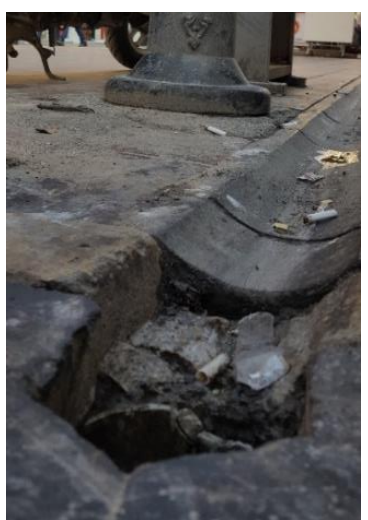

(c)

Şekil 23. (a) Büyük mazgallar, (b) Küçük mazgallar, (c) Su yollarının sonundaki delikler.

Bitkiler sokaklarda yürümeye bir engel olarak görülebilmektedir. Fakat mekanların daha sicak algılanmasına sebep olmaktadırlar ve kullanıcıları bulundukları bölgelere çekerek yürünebilirliği pozitif yönde etkiledikleri söylenebilmektedir. Alandaki ağaç analizine bakıldığında ağaçların Gaziantep Caddesi boyunca sıralandığı görülmektedir (Şekil 24).

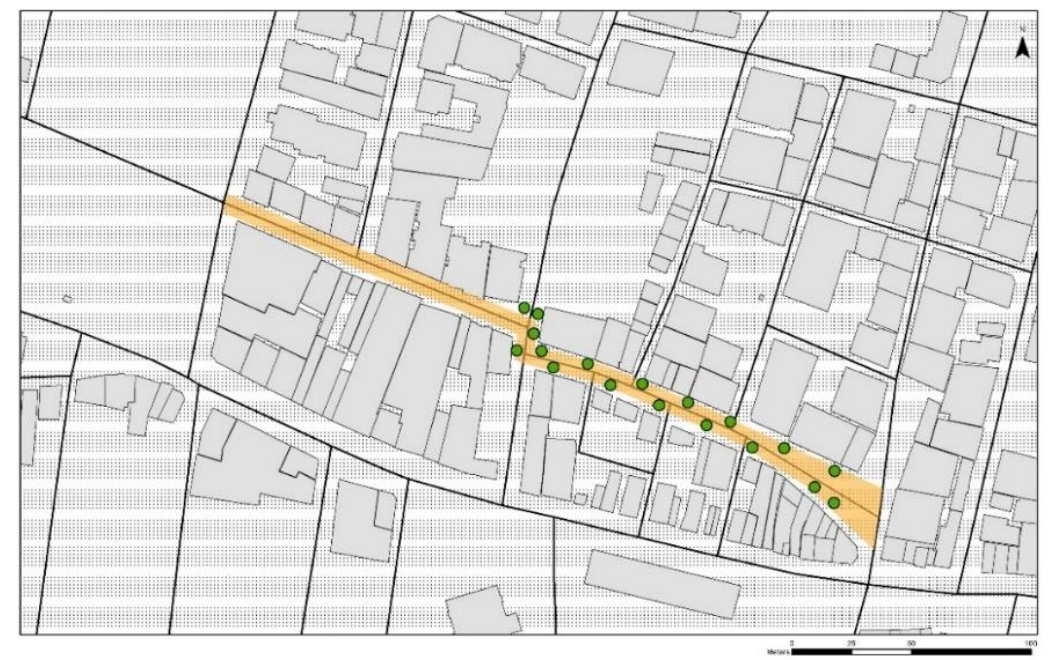

Şekil 24. Ă̆aç Konumları Analizi. 
Kentsel alanlarda yapılacak ağaçlandırmaların öncelikle kullanıcılarının beklentilerini, kentin estetik ve işlevselliğini karşılayabilecek etkili bir tasarım ve planlamaya sahip olması, gelecekteki gelişmeleri dikkate alması gerekmektedir [51].

Kentsel tasarım projeleri yapılırken sokak, cadde ve yolun tasarımı, aydınlatma direkleri, elektrik ve telefon hatları, kanalizasyon, drenaj gibi alt yapı donanımları ayrıca dikkate alınmalıdır. Ağaçların dikim yerleri bu tesislere zarar vermeyecek şekilde ve onarımlarına engel olmayacak şekilde belirlenmelidir [52].

Ağaç türlerinin taç yüksekliği ve genişliği ile sokak aydınlatma elemanları, elektrik ve telefon kabloları vb. yapılar kesişmemelidir. Yaya ve taşıt trafiğinin engellenmemesi için yollarda bulunan ağaç taçlarının altında yayalar için en az $2.5 \mathrm{~m}$, taşıtlar için ise en az $4.5 \mathrm{~m}$ taç altı yüksekliği olmalı ve bu yükseklik dikim sırasında göz önünde bulundurulmalıdır. Taç altı yüksekliği sağlanıncaya kadar ve doğal taç görünümü bozulmayacak şekilde budama yapılmalıdır [52].

Çalışma alanındaki ağaç konumlarına ve yüksekliklerine bakıldığında sokak aydınlatmalarının aralarına belirli aralıklarla dikildiği, yakınlarında bulunan yapılara mesafeli bir şekilde konumlandırıldığı, budanmış hallerinin ise Şekil 25 ’te de görüldüğü gibi yaya ölçeğinde yürümeyi engellemediği belirlenmiştir.
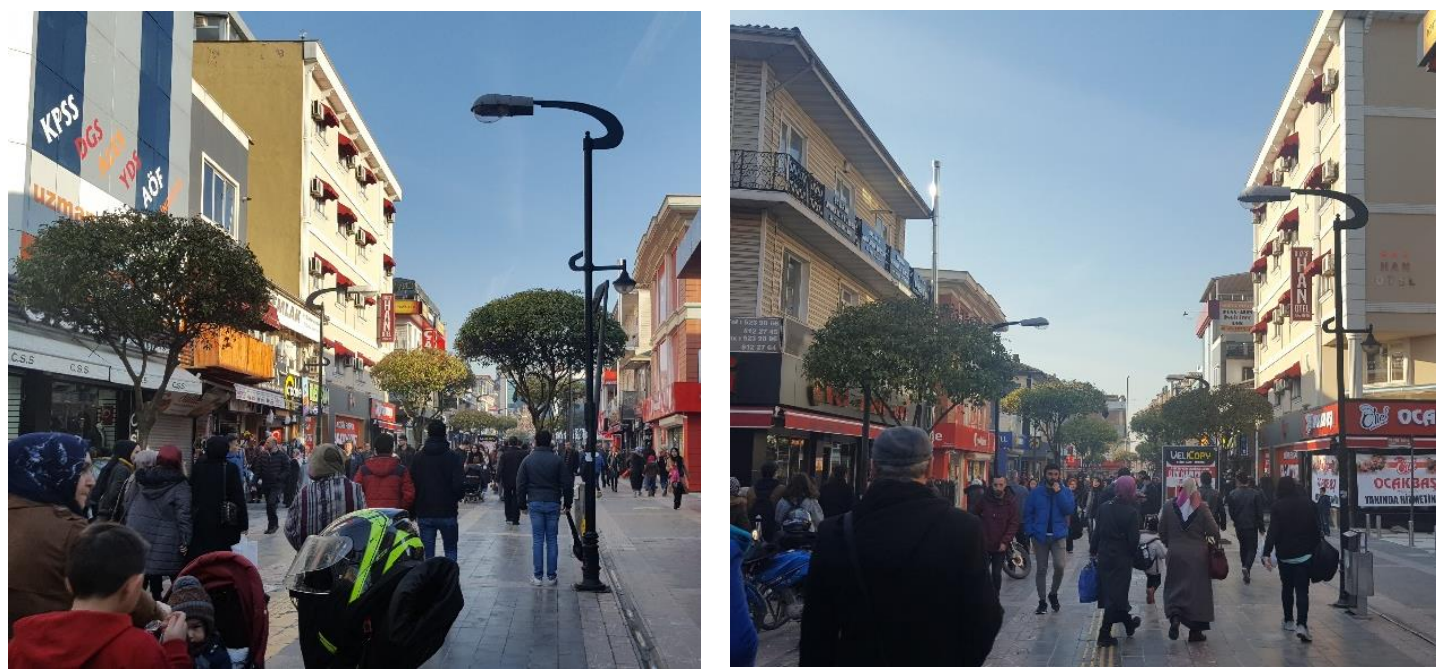

Şekil 25. Çalışma alanindan ă̆aç görselleri.

\section{IV.SONUC}

$\mathrm{Bu}$ araştırmada, nitel ve nicel ölçütler ile çalışmada elde edilen verilerin değerlendirilmesi sonucunda mekânların yürünebilirlik kapasitesini bulmaya yönelik analizler yapılmıştır; analizler sonucunda, Düzce ili merkez ilçesinin ana omurgalarından olan Spor Sokak ve Gaziantep Caddesi test edilmiştir. Tasarım ölçütlerinden bağlam, erişilebilirlik, çeşitlilik, ölçek, yoğunluk, güvenlik, konfor ve çevresel algı kriterleri üzerinden alandaki yürünebilirlik değerinin ölçülmesi hedeflenmiştir.

Alanda yapılan anket ve gözlem çalı̧̧maları Rapoport (1977) [47]'nin algılama süreçleri çizelgesine göre değerlendirildiğinde elde edilen nitel veriler; bireyin fiziksel özelliklerinden cinsiyet, yaş ve algının; bireyin sosyo-psikolojik özelliklerinden öğrenim seviyesi ve mesleğinin; fiziksel çevre koşullarından yaşanılan yerin ve yaşam süresi ile bunlara ek olarak alanın kullanılma sebebi ve saatinin mekanı algılamada farklı1ıklara neden olduğunu göstermiştir. Mekanı algılamada kadınlar bu alanı yeterince bakımlı, konforlu ve modern bulmamışlardır. Yaş ilerledikçe mekanın olumlu algılandığı fakat gençlerin beklentilerini yeterince karşılamadığı görülmüştür. Yine aynı şekilde eğitim seviyesi arttıkça 
memnuniyetsizliğinde arttı̆̆ 1 görülmektedir. Düzce ilinde yaşanmışlık süresi arttıkça sokakların daha olumlu özelliklere sahip olduğu vurgulanmış, yaşanılan yerin niteliğine göre ise olumlu olarak tariflenmesi doğru orantılı bir şekilde gerçekleşmiştir. Yaşanmışlık, aidiyet duygusunu güçlendirmekte ve sosyal mekan olarak sürekli kullanılan kent mekanlarına sahip çıkıldığını göstermiştir. Kullanım saatlerine göre bakıldığında ise en çok öğle saatlerindeki kullanımda olumlu yanıtlar alınmıştır. Kullanım sebeplerinden mekanı iş için kullananlar yeme-içme, eğlence, alışveriş için kullananlara göre beklentilerinin az olmasından dolayı daha olumlu cevaplar vermişlerdir.

Nicel veri kriterleri de aşağıdaki şekilde yorumlanabilir;

- Bağlam: Spor Sokak ve Gaziantep Caddesi konumu bakımından Düzce ilinin merkez bölgesinde bulunmaktadır. Belediye, valilik binası, cami, meydan gibi kamusal alanlara yakın bir konumda olması yürünebilirlik değerini olumlu etkilemektedir.

- Erişilebilirlik: Izgara sisteme sahip, güvenli sokak dokusu ve küçük yapı adaları ile erişilebilirlik değeri yüksektir. Eğimin olmaması, zemin döşeme malzemesinin yürümeye engel olmaması ile eşit erişilebilir sokaklardır.

- Çeşitlilik: Farklı işlevli mekanların bir arada olması bu sokakları daha eğlenceli ve canlı hale getirmektedir. Kent merkezinde yemek, alışveriş, ticaret, ofis, kültürel kullanımlarla birlikte, turizm, eğlence, konut işlevlerinin iç içe bulunması, mekanın 24-saat yaşayan bir yer olmasını böylece canlılığın ve algılanan güvenliğin artırılmasını sağlamaktadır.

- Ölçek: Deprem bölgesinde bulunması sebebi ile çok yüksek katlı binaların yapılamaması ve alanda mevcut binaların en yüksek 5 katlı olması insan ölçeğinde bir mekanı tanımlar. Sokak boyunca uzanan yapıların birbirine olan mesafesi kısmen kapalıl1k hissini vermekte ve alanı tanımlı hale getirmektedir.

- Yoğunluk: İnsan, işlev ve yapı yoğunluğu bakımından değerlendirildiğinde; en çok günün öğle saatlerinde kullanıc1 yoğunluğu olduğu gözlemlenmiştir. Sokak boyunca karşılıklı olarak bulunan zemin katlardaki iş yeri sayısı çeşitlilik bakımından ihtiyacı karşılayamasa da orantilidir.

- Güvenlik: Sokak lambaları ve güvenlik kameraları suç işleme eyleminde caydırıcı olduklarından kullanıcının özellikle akşam saatlerinden sonra kendisini güvende hissetmesini ve rahat bir şekilde yürüyebilmesine sebep olmaktadırlar. Alandaki sokak lambaları ve güvenlik kameralarının arttırılması sağlanabilir.

- Konfor: Sokakların döşeme niteliği, sokaklardaki engeller, reklam panoları, sokak aydınlatması, çöp kutuları, peyzaj öğelerinin varlığı ve konumları gibi unsurların her iki yaya yolunda bütünsel olarak ele alınarak, her kesimden kullanıcıya (eğitim seviyesi, gelir düzeyi vb.) hitap edebilecek bir çalışma bu mekanların daha yaşanabilir hale gelmesine katkı sağlayacaktır. Sadece geçiş yeri özelliğinde olan bir takım oturma nişleri, peyzaj elemanlarının eklenmesi ile mekansal kalitenin arttırılması öngörülmektedir.

Ayrıca çalışmanın bu bölgede yapılması planlanan kentsel tasarım projeleri için kullanıcıların fiziksel ve sosyo-psikolojik özellikleri analizleri ile alanın fiziksel analizlerin değerlendirilmesi yönü ile bir altlık olabileceği; bireylerin ihtiyaç ve beklentilerinin planlanarak tasarım sürecinin gelişmesi daha yürünebilir kentlerin oluşacabileceği yönü ile de bir öneri olacağı düşünülmektedir.

TEȘEKKÜR: Bu çalışma Düzce Üniversitesi Bilimsel Araştırma Projeleri tarafından desteklenmiştir (Proje no: 2019.09.04.915). 


\section{KAYNAKLAR}

[1] G. Ertuğrul, "Kentsel mekanda yürünebilirlik olgusu: Moda ve Bahariye aksları," Yüksek Lisans tezi, Mimarlık Bölümü, İstanbul Teknik Üniversitesi, İstanbul, Türkiye, 2019.

[2] T. A. Litman. (2020, September 20). Economic Value of Walkability [Online]. Available: https://www.vtpi.org/walkability.pdf.

[3] R. H. Lo, "Walkability: What is it?," Journal of Urbanism, vol. 2, no. 2, pp. 145-166, 2009.

[4] H. Krambeck, J. Snah, "The global walkability index: Talk the walk and walk the talk," presented at The Better Air Quality Conference (BAQ), Yogyakarta, Indonesia. 2006.

[5] M. Greenberg, J. Renne, "Where does walkability matter the most? An environmental justice interpretation of New Jersey data," Journal of Urban Health: Bulletin of the New York Academy of Medicine, vol. 82, no. 1, pp. 90-100, 2005.

[6] M. Southworth, "Designing the walkable city," Journal of Urban Planning and Development, vol. 131, no. 4, pp. 246-257, 2005.

[7] Z. Y. Halu, "Kentsel mekan olarak caddelerin mekansal karakterinin yürünebilirlik bağlamında irdelenmesi Bağdat Caddesi örneği," Doktora tezi, Mimarlık Bölümü, İstanbul Teknik Üniversitesi, İstanbul, Türkiye, 2010.

[8] T. Pikora, B. G. Corti, F. Bull, K. Jamrozik, R. Donovan, "Developing a framework for assesment of the environmental determinants of walking and cycling," Social Science \& Medicine, pp. 1693-1703, 2003.

[9] A. Tekel, Y. Özalp, "Mekanın fiziksel ve algısal niteliğinin yürünebilirliğe ve mekanda yürümeden duyulan memnuniyete etkisi: Ankara Atatürk Bulvarı örneği," Planlama, c. 26, s. 1, ss. 40$50,2016$.

[10] C. Bradshaw, "Creating -- and using -- A rating system for neighborhood walkability towards an agenda for "Local Heroes," presented at 14th International Pedestrian Conference, Boulder, Colorado, 1993.

[11] R. Ewing, S. Handy, R. C. Brownson, O. Clemente, E. Winston, "Identiying and measuring urban design qualities related to walkability," Journal of Walkability Physical Activity and Health, vol. 3, no. 1, pp. 223-240, 2006.

[12] A. Rapoport, History and Precedent in Environmental Design, USA, New York: Plenum Press, 1990.

[13] J. Jacobs, Çev. B. Doğan, Büyük Amerikan Şehirlerinin Ölümü ve Yaşamı, İstanbul, Türkiye: Metis Yayınc1lik, 2011.

[14] J. L. Kriken, P. Enquist, R. Rapoport, City Building: Nine Planning Principles for The Twenty First Century, New York: Princeton Architectural Press, 2010.

[15] B. E. Saelens, J. F. Sallis, J. B. Black, D. Chen, "Neighborhood-based differences in physical activity: an environment scale evaluation," American Journal of Public Health, vol. 93, no. 9, pp. 1552$1558,2003$.

[16] B. Bielefeld, S. El Khouli, Adım Adım Tasarım Fikirleri, İstanbul, Türkiye: Yem Yayınları, 
2005, ss. $15-32$.

[17] F. Tigges, A. Janson, Fundamental Concepts of ARChitecture: The Vocabulary of Spatial Situations, Basel, Switzerland: Birkhäuser, 2014.

[18] A. Madanipour, Urban Design, Space and Society, London, UK: Palgrave Macmillian, 2014.

[19] W. G. Hansen, "How accessibility shapes land-use," Journal of the American Institute of Planners, vol. 25, no. 2, pp. 25,73-76, 1959.

[20] L. D. Burns, Transportation, Temporal, and Spatial Components of Accessibility, Toronto, Canada: Lexington Books, 1979.

[21] C. Bhat, S. Handy, K. Kockelman, H. Mahmassani, Q. Chen, I. Srour, L. Weston, “Assessment of accessibility measure," Center for Transportation Research, Univ. Texas, Austin, Rep. FHWA/TX01/4938-3. Aug. 2001.

[22] M. Özuysal, "Şehirsel yerleşimlerde erişilebilirlik ölçütünün modellenmesi ve kullanımı: Ulaşım türü seçimi üzerindeki etkisinin incelenmesi,” Doktora tezi, İnşaat Mühendisliği Bölümü, Dokuz Eylül Üniversitesi, İzmir, Türkiye, 2010.

[23] J. Gehl, Cities for People, Washington DC, USA: Island Press, 2010.

[24] M. İnceoğlu, "Açık mekanların kalite açısından değerlendirilmesine yönelik bir yaklaşım: İstanbul meydanlarının incelenmesi," Doktora tezi, Mimarlık Bölümü, Yıldız Teknik Üniversitesi, İstanbul, Türkiye, 2007.

[25] R. Ewing, G. Meakins, G. Bjarnson, H. Hilton, Making Healthy Places; Designing and Building For Health, Well-being, and Sustainability, Washington DC, USA: Island Press, 2011, pp. 149-169.

[26] A. Rapoport, Culture, Architecture, and Design, Chicago, USA: Locke Science Publishing Company, Inc., 2005.

[27] F. D. K. Ching, Çev. S. Lökçe, Mimarlık: Biçim, Mekân ve Düzen, İstanbul, Türkiye: Yap1 Endüstri Merkezi Yayınları, 2002, ss. 278.

[28] F. D. K. Ching, Çev. Ç. Birkan, Mimarlık ve Sanatta Yaratıcı Bir Süreç, İstanbul, Türkiye: Yap1 Endüstri Merkezi Yayınları, 2003, ss. 65.

[29] F. D. K. Ching, Çev. B. Elçioğlu, İç Mekân Tasarımı İstanbul, İstanbul, Türkiye: Yapı Endüstri Merkezi Yayınları, 2004, ss. 136-138.

[30] C. Moughtin, Urban Design: Street and Square, Oxford, UK: Architectural Press, 1992.

[31] G. Banz, Elements of Urban Form, New York, USA: McGraw-Hill Book Company, 1970.

[32] J. Speck, Walkable City: How Downtown Can Save America, One Step at a Time, New York, USA: North Point Press, 2012.

[33] M. A. Alfonzo, "To walk or not to walk? The hierarchy of walking needs," Environment and Behavior, vol. 37, no. 6, pp. 808-836, 2005.

[34] J. Massengale, V. Dover, Street Design the Secret to Great Cities and Towns, New Jersey, USA: John Wiley \& Sons, Inc., 2013. 
[35] K. Lynch, Çev. İ. Başaran, Kent İmgesi, İstanbul, Türkiye: İş Bankası Kültür Yayınları, 2011.

[36] P. von Meiss, Elements of Architecture: From Form to Place, Londra, UK: E\&FN Spon, 1990.

[37] C. Alexander, S. Ishikawa, M. Silverstein, A Pattern Language: Towns, Buildings, Construction: 2, New York, USA: Oxford University Press, 1977.

[38] N. Bayramoğlu, "Kullanıcı algısı bağlamında kentsel kimlik: Barbaros Bulvarı-Büyükdere kentsel aksı," Yüksek Lisans tezi, Kentsel Tasarım Bölümü, İstanbul Teknik Üniversitesi, İstanbul, Türkiye, 2010.

[39] S. Malek, "Mekansal bilişim: Mekan dizim yönteminin Beyazıt, İstanbul kapsamında uygulanması," Yüksek Lisans tezi, Kentsel Tasarım Bölümü, İstanbul Teknik Üniversitesi, İstanbul, Türkiye, 2015.

[40] C. Norberg-Schulz, Intentions in Architecture, London, UK: Allen and Unwin Ltd., 1966.

[41] D. Linaraki, G. Voradaki, "The interaction of space with the human nervous system and its impact on human psychology," presented at Academy of Neuroscience for Architecture Conference (Salk Institute for Biological Studies), San Diego, California, 2012.

[42] D. Cüceloğlu, Insan ve Davranışı, İstanbul, Türkiye: Remzi Kitapevi A.Ş., 1991.

[43] M. Banasiak, "Cultivating a culture for neuro-architecture: Linking cognitive science to architectural experience in design education," presented at Academy of Neuroscience for Architecture Conference (Salk Institute for Biological Studies), San Diego, California, 2012.

[44] T. P. McNamara, J. Sluzenski, B. Rump, "Human spatial memory and navigation," in Learning and Memory: A Comprehensive Reference, 1st ed., Cambridge, USA: Academic Press, 2008, ch. 4, pp. 157-178.

[45] İ. E. Kürkçüoğlu, "Kentsel dokuda yaya hareketlerinin mekansal ve psikolojik etki değerlendirmesi," Doktora tezi, Şehir ve Bölge Planlama Bölümü, İstanbul Teknik Üniversitesi, İstanbul, Türkiye, 2015.

[46] W. H. Ittelson, Visual Space Perception, New York, USA: Springer Pub. Co, 1960, pp. 12411242.

[47] A. Rapoport, Human Aspects of Urban Form, Oxford, UK: Pergamon Press, 1977, pp. 38.

[48] K. Lynch, The Image of the City, Massachusetts, USA: The M.I.T. Press, 1960.

[49] M. J. O'Neill, "Effects of signage and floor plan configuration on wayfinding accuracy," Environment and Behavior, vol. 23, no. 5, pp. 553-574, 1991.

[50] S. Kılıç, "Cronbach's Alpha reliability coefficient," Journal of Mood Disorders (JMOOD), vol. 6, no. 1, pp. 47-48, 2016.

[51] S. Ürgenç, "Kent ağaçlarının yetiştirilmesi, bakımı ve korunmaları konusunda bazı öneriler," Kent Ağaçlandırmaları ve İstanbul Sempozyumu’nda sunuldu, İstanbul, Türkiye 1998.

[52] Şehiriçi yol ve meydan ağaçlandırma kuralları, TSE 8146 Standart, 1990. 